\title{
Abhandlungen
}

\section{Exploring the Autonomy of the European Union Legal Order}

Koen Lenaerts

President of the Court of Justice of the European Union and Professor of European Union Law, Leuven University, Leuven, Belgium

Koen.Lenaerts@curia.europa.eu

José A. Gutiérrez-Fons

Legal Secretary at the Court of Justice of the European Union, Luxembourg Jose_Antonio.Gutierrez-Fons@curia.europa.eu

Stanislas Adam

Legal Secretary at the Court of Justice of the European Union and Professor of European Union Law, Ghent University (G. E. L. I.), Ghent, Belgium Stanislas.Adam@curia.europa.eu*

Abstract

$\begin{array}{lr}\text { Keywords } & 48\end{array}$

$\begin{array}{lr}\text { I. Introduction } & 48\end{array}$

II. What EU Law Is Not $\quad 52$

1. EU Law Is Not Ordinary International Law

a) General Observations $\quad 52$

b) An Example: The EU System of Fundamental Rights Protection 54

2. EU Law Is However Open to International Law

III. What EU Law Is $\quad 59$

1. The Incorporation of External Norms Into the EU Legal Order 60

2. The Transnational Dimension of Autonomy 69

3. The Principle of Direct Effect $\quad 75$

4. The Absence of Normative Gaps $\quad 78$

5. Normative Conflicts and Value Diversity 80

6. The Treaties and the Charter as a 'Living Instrument' 84

$\begin{array}{ll}\text { IV. Concluding Remarks } & 87\end{array}$

\section{Abstract}

Two different dynamics govern the autonomy of the European Union (EU) legal order. On the one hand, autonomy seeks to define what EU law is

\footnotetext{
* All opinions expressed herein are personal to the authors.
} 
not, i. e. it is not ordinary international law. Positively, on the other, autonomy seeks to define what EU law is, i. e. a legal order that has the capacity to operate as a self-referential system of norms that is both coherent and complete. Yet the concept of autonomy of the EU legal order in no way conveys the message that the EU and its law are euro-centric and that the Court of Justice of the European Union (the 'Court of Justice') seeks to insulate EU law from external influences by building walls that prevent the migration of legal ideas. Autonomy rather enables the Court of Justice to strike the right balance between the need to preserve the values on which the $\mathrm{EU}$ is founded and openness to other legal orders. The autonomy of the EU legal order is thus part of the very DNA of that legal order as it allows the EU to find its own constitutional space whilst interacting in a cooperative way with its Member States and the wider world.

\section{Keywords}

Autonomy of the EU legal order - Ordinary International Law - SelfReferential System of Norms - Balancing Exercise - MOX Plant - Kadi I and II - Opinion 1/09-Melloni - Opinion 2/13 - Achmea - Opinion 1/17

\section{Introduction}

The autonomy of the EU legal order serves to explain both the relationship between EU law and international law and that between EU law and the laws of the Member States. That autonomy has drawn a great deal of interest from academics since the Court of Justice of the European Union (the 'Court of Justice' or the 'Court') gave its rulings in Opinion $2 / 13,{ }^{1}$ and more recently, in Opinion 1/17. ${ }^{2}$ That is perhaps unsurprising as those Opinions contain what is probably the most detailed and comprehensive analysis of that autonomy. ${ }^{3}$

1 CJEU, Accession of the European Union to the ECHR, Opinion 2/13 of 18 December 2014, EU:C:2014:2454.

2 CJEU, EU-Canada CET Agreement, Opinion 1/17 of 30 April 2019, EU:C:2019:341.

3 See, generally, René Barents, The Autonomy of Community Law (The Hague: Kluwer Law International, 2004), and Jan Klabbers and Panos Koutrakos (eds), 'Special Issue: An Anatomy of Autonomy', Nord. J. Int'l L. 88 (2019), 1 et seq. As to Opinion 2/13, see, e. g., Dimitry Kochenov, 'EU Law Without the Rule of Law: Is the Veneration of Autonomy Worth It?', YBEL 34 (2015), 74-96; Eleanor Spaventa, 'A Very Fearful Court? The Protection of Fundamental Rights in the European Union after Opinion 2/13', Maastricht J. Eur. \& Comp. L. 
A close reading of those opinions suggests that the autonomy of the EU legal order highlights the fact that the founding Treaties of the EU are not 'ordinary international treaties'. ${ }^{4}$ Such a reading also shows that that autonomy serves to protect the core values and structural tenets on which the EU is founded. However, we respectfully disagree with those scholars who posited, in the aftermath of Opinion 2/13, that the concept of autonomy of the EU legal order operates, first and foremost, as a means of protecting the prerogatives of the Court of Justice at all costs and of insulating the EU from all external influence. ${ }^{5}$ In our view, the autonomy of the EU legal order is part of the very DNA of that legal order, allowing the EU to find its own constitutional space whilst interacting in a cooperative way with its Member States and the wider world.

That said, before explaining why that is the case, it is important, when examining the concept of autonomy of the EU legal order, to begin by revisiting the classics. This is because the process of constitutionalising the EU legal order and autonomy go hand in hand. As is well known, the 'constitutionalisation' of the EU integration project began five decades ago

and Comparative Law 22 (2015), 35-56; Piet Eeckhout, 'Opinion 2/13 on EU Accession to the ECHR and Judicial Dialogue - Autonomy or Autarky?’, Fordham Int'l L. J. 38 (2015), 955-992, and Steve Peers, 'The EU's Accession to the ECHR: The Dream Becomes a Nightmare', GLJ 16 (2015), 213-222. But see Daniel Halberstam, “It's the Autonomy, Stupid!” A Modest Defence of Opinion 2/13 on EU Accession to the ECHR, and the Way Forward', GLJ 16 (2015), 105-146; Fabrice Picod, 'La Cour de justice a dit non à l'adhésion de l’Union européenne à la Convention EDH. - Le mieux est l'ennemi du bien, selon les sages du plateau du Kirchberg, Semaine Juridique Edition Générale (2015), 230-234, and Jiří Malenovský, 'Comment tirer parti de l'avis $2 / 13$ de la Cour de l'Union européenne sur l'adhésion à la Convention européenne des droits de l'homme', R. G. D. I.P. 119 (2015), 705-742. Regarding Opinion 1/17, see Special issue: Collection of Reflection Essays on Opinion 1/17, Europe and the World 4 (2020). See also Maria Fanou, 'The CETA ICS and the Autonomy of the EU Legal Order in Opinion 1/17 - A Compass for the Future', Cambridge Yearbook of European Legal Studies (2020), 1-27; Eleftheria Neframi, 'Permanent Investment Courts and the EU Legal Order', European Yearbook of International Economic Law (2020); Alan Hervé, 'Défendre l'ordre juridique de l'Union en exportant ses valeurs et instruments fondamentaux', Revue Trimestrielle de Droit Européen 56 (2020), 107-125, and Koen Lenaerts, 'Le cadre constitutionnel de l'Union et l'autonomie fonctionnelle de son ordre juridique', in: David Petrlík, Michal Bobek and Jan M. Passer (eds), Évolution des rapports entre les ordres juridiques de l'Union européenne, international et nationaux. Liber amicorum Jiř́ Malenovský (Bruylant: Bruxelles, 2020), 285-306.

4 CJEU, Accession of the European Union to the ECHR (n. 1), para. 157.

5 See, e. g., Spaventa (n. 3), 56 (who pointed out that in Opinion 2/13, the Court of Justice 'seems more focused on protecting its own prerogatives than it is in protecting fundamental rights [or even the EU constitutional structure]'), and Eeckhout (n. 3), 991 (who observed that '[it] is one thing to conceive of European legal orders or systems - national law, EU law, and [ECHR] law - as having their own identity and autonomy. It is another to conceive of them as self-contained and unbridgeable'). 
when the Court of Justice delivered its ground-breaking judgment in van Gend en Loos. ${ }^{6}$ As Pernice observes, in van Gend en Loos, the Court of Justice planted the seeds of an autonomous legal order. ${ }^{7}$ In a famous passage of that judgment, the Court held that

'[...] the [EU] constitutes a new legal order of international law for the benefit of which the States have limited their sovereign rights, albeit within limited fields, and the subjects of which comprise not only the Member States but also their nationals' ${ }^{8}$

Contrary to the position in relation to international agreements in general, the Court of Justice held that it is not for the constitutions of the Member States to determine whether an EU Treaty provision may produce direct effect, as that determination is to be found in 'the spirit, the general scheme and the wording' of the EU Treaty itself. Questions regarding the direct effect of EU law are to be solved in the light of the Treaties themselves, as interpreted by the Court of Justice. ${ }^{9}$ That judgment constitutes a constitutional moment in the history of European integration, whose 'foundational significance' some scholars compare to the ruling of the US Supreme Court in Marbury v. Madison. ${ }^{10}$ By conferring directly enforceable rights that national courts must protect effectively, EU law does not merely create mutual obligations between the contracting parties but places individuals centre stage in the process of integration. Unlike ordinary international law, courts and individuals have played a leading role in that process.

Moreover, it follows from the seminal judgment of the Court of Justice in Costa v. ENEL, which contains the first explicit reference to the concept of autonomy, ${ }^{11}$ that EU law is not 'foreign law' but it is rather by its very nature

6 CJEU, van Gend en Loos, judgment of 5 February 1963, case no. 26/62, EU:C:1963:1. See Antonio Tizzano, Juliane Kokott and Sacha Prechal (eds), 50th Anniversary of the Judgment in van Gend en Loos (Luxembourg: EU Publications Office, 2013).

7 Ingolf Pernice, 'The Autonomy of the EU Legal Order - Fifty Years After Van Gend' in: Antonio Tizzano, Juliane Kokott and Sacha Prechal (eds) (n. 6), 55-80 (56).

8 CJEU, van Gend en Loos (n. 6).

9 Bruno de Witte, 'The Impact of Van Gend en Loos on Judicial Protection at European and National Level: Three Types of Preliminary Questions' in: Antonio Tizzano, Juliane Kokott and Sacha Prechal (eds) (n. 6), 93-103 (93) (who rightly observes that ' $[\mathrm{t}]$ he crucial contribution of the 1963 judgment was [...] that the question whether specific provisions of the EEC Treaty (or, later, secondary Community law) had direct effect was to be decided centrally by the [Court of Justice] instead of by the various national courts according to their own views or national habits on the matter').

10 Daniel Halberstam, 'Pluralism in Marbury and Van Gend' in: Miguel Poiares Maduro and Loïc Azoulai (eds), The Past and Future of EU Law: The Classics of EU Law Revisited on the 50th Anniversary of the Rome (Oxford: Hart Publishing, 2010), 26-36.

11 See CJEU, Costa v. ENEL, judgment of 15 July 1964, case no. 6/64, EU:C:1964:66, at 594. In that judgment, the Court of Justice refers to the law stemming from the Treaty as 'an 
and in its own right 'an integral part of the legal systems of the Member States'. ${ }^{12}$ This means, in essence, that in order for EU law to have the same meaning throughout the EU and thus, to ensure equality before the law, that law must become both part of the laws of the Member States and our common law as Europeans. ${ }^{13}$ By being uniformly interpreted and applied, EU law is German law as it is Greek, Slovenian, Dutch, Swedish, Spanish, French, Italian, Polish law - and so on. Accordingly, as the Court of Justice held in Costa v. ENEL, EU law must prevail over conflicting provisions of national law because it is the law that is common to all Member States. If EU law is to remain the 'law of the land' that is common to all Member States, no one part of the 'land' may hinder the operation of 'the law'. The commonality of EU law requires that law to be autonomous. ${ }^{14}$

It follows from van Gend en Loos and Costa v. ENEL that the autonomy of the EU legal order is governed by two different, albeit mutually reinforcing, dynamics. Negatively, autonomy seeks to define what EU law is not, i. e. it is not ordinary international law. Positively, autonomy seeks to define what $E U$ law is, i.e. a legal order that has the capacity to operate as a selfreferential system of norms that is both coherent and complete. ${ }^{15}$ The present contribution will focus on exploring those two dynamics of autonomy. ${ }^{16}$ To

independent source of law'. However, in the French, German, Italian and Dutch versions of that judgment, the Court uses the expression an 'autonomous source' of law instead (respectively, une 'source autonome' de droit, eine 'autonom[e] Rechtsquelle', 'una fonte autonoma' di diritto, and 'een autonome [rechts]bron' ). See, in this regard, Pernice (n. 7), 56.

12 See CJEU, Costa v. ENEL (n. 11), 593.

13 See, in this regard, Pernice (n. 7), 58.

14 See, in this regard, Koen Lenaerts, 'No Member State is More Equal than Others: The Primacy of EU Law and the Principle of the Equality of the Member States before the Treaties', VerfBlog, 2020/10/08, <https://verfassungsblog.de>. See also Opinion of AG Tanchev delivered on 17 December 2020 in case no. C-824/18, A.B. and Others, EU:C:2020:1053, point 82.

15 Eckes correctly captures the main feature of autonomy as the 'self-referential character of EU law', meaning in essence, that 'EU law stems from an independent origin and does not depend for its validity on either national or international law', see Christina Eckes, 'The Autonomy of the EU Legal Order', Europe and the World: A Law Review (2020), 1-19 (18). See also Koen Lenaerts and José A. Gutiérrez-Fons, 'The European Union: a Constitutional Perspective' in: Robert Schütze and Takis Tridimas (eds), Oxford Principles of European Union Law Volume I: The European Union Legal Order (Oxford, OUP, 2018), 103-141, positing, in Hartian terms, that the EU legal order has its own 'rule of recognition' understood 'as a shared plan which sets out the constitutional order of a legal system'. See, in this regard, Scott J. Shapiro, 'What is the Rule of Recognition? (and Does It Exist?)', in: Matthew Adler and Kenneth Einar Himma (eds), The Rule of Recognition and the US Constitution (Oxford: Oxford University Press, 2009) 235-268.

16 Those two dynamics of autonomy may also be recast as 'wall-identity' referring to 'the act of making something distinct from something else' and as 'mirror-identity' 'consisting of the positive identification of some common elements through a moment of self-reflection'. See, in this regard, Giuseppe Martinico, 'The autonomy of EU law: A Joint Celebration of Kadi II 
that effect, it is divided into two parts, each focusing on one of those two dynamics. Finally, a brief conclusion supports the contention that the concept of autonomy of the EU legal order in no way conveys the message that the EU and its law are euro-centric and that the Court of Justice seeks to insulate EU law from external influences by building walls that prevent the migration of legal ideas.

\section{What EU Law Is Not}

\section{EU Law Is Not Ordinary International Law}

\section{a) General Observations}

The autonomy of the EU legal order may be defined in a negative fashion that serves to highlight 'the enduring sense that the EU legal order is distinctive'. ${ }^{17}$ In a nutshell, EU law is not ordinary international law. ${ }^{18}$

Traditionally, ordinary international law has operated on the assumption that actions brought by a contracting party against another contracting party are sufficient to guarantee respect for an international agreement. However, in van Gend en Loos, the Court of Justice rejected that assumption with regard to EU law. It explained that if the judicial protection of EU rights were limited to infringement proceedings brought by the European Commission (or a Member State), that limitation 'would remove all direct legal protection of the individual rights of [Member State] nationals'. Hence, the judicial protection of EU rights is based on a system of 'dual vigilance': in addition to the supervision carried out by the European Commission and the Member States when bringing an infringement action against a defaulting Member State, individuals are entitled to rely on their EU rights in the national courts. ${ }^{19}$

Van Gend en Loos established the autonomy of the EU legal order vis-àvis international law. In the following years, the Court of Justice adopted a

and Van Gend en Loos' in: Matej Avbelj, Filippo Fontanelli and Giuseppe Martinico (eds), Kadi on Trial: A Multifaceted Analysis of the Kadi Trial (London-New York: Routledge, 2014), 157171.

17 Niamh Nic Shuibhne, 'What is the Autonomy of EU Law, and Why Does that Matter?', Nord. J. Int'l L. 88 (2019), 9-40 (10).

18 This is what some authors refer to as 'external autonomy'. See, in this regard, Bruno de Witte, 'The Relative Autonomy of the European Union's Fundamental Rights Regime', Nord. J. Int'l L. 88 (2019), 65-85 (66).

19 CJEU, van Gend en Loos (n. 6). 
discourse that continued to distance itself from international law. ${ }^{20}$ Whilst in van Gend en Loos, it still wrote that 'the [EU] constitutes a new legal order of international law', ${ }^{21}$ in subsequent judgments, the expression 'of international law' was abandoned by the Court. ${ }^{22}$

In Costa v. ENEL, the Court of Justice ruled that '[by] contrast with ordinary international treaties, the EEC Treaty has created its own legal system which, on the entry into force of the Treaty, became an integral part of the legal systems of the Member States and which their courts are bound to apply'. ${ }^{23}$ In the same way, in Commission v. Luxembourg and Belgium, ${ }^{24}$ decided four months later, the Court of Justice refused to apply, in the context of infringement proceedings, the principle of international law according to which 'a party, injured by the failure of another party to perform its obligations, [may] withhold performance of its own' (the so-called 'exceptio non adimpleti contractus'). '[T] reciprocal obligations between the different natural and legal persons to whom it is applicable', the Court wrote, 'but establishes a new legal order which governs the powers, rights and obligations of the said persons, as well as the necessary procedures for taking cognisance of and penalising any breach of it'. ${ }^{25}$ That judgment was a major contribution to a functional understanding of autonomy of the EU legal order. The proper functioning of the EU would be seriously undermined if a Member State could refuse to comply with its EU law obligations in situations where that Member State claims having suffered harm as a result of another Member State's violation of that law. Granting each Member State such unilateral right to 'opt-out' from its own obligations imposed by EU law, based on its own perception or belief that another Member State violates EU law, would be clearly at odds with the very idea of political and legal solidarity underlying the entire EU project.

That willingness to distance EU law from ordinary international law was again apparent in Opinion 1/91, in which the Court of Justice refused to

20 See, in this regard, Eileen Denza, 'Placing the European Union in International Context: Legitimacy of the Case Law' in: Maurice Adams, Henri de Waele, Johan Meeusen and Gert Straetmans (eds), Judging Europe's Judges. The Legitimacy of the Case Law of the European Court of Justice (Oxford: Hart Publishing, 2013).

21 Denza (n. 20) (emphasis added).

22 See, e. g., CJEU, Commission v. Council, judgments of 28 April 2015, case no. C-28/12, EU:C:2015:282, para. 39, and CJEU, Wightman and Others, judgment of 10 December 2018, case no. C-621/18, EU:C:2018:999, para. 44.

23 CJEU, Costa v. ENEL (n. 11).

24 See, e. g., CJEU, Commission v. Luxembourg and Belgium, judgment of 13 November 1964, joined cases nos 90/63 and 91/63, EU:C:1964:80, 631.

25 CJEU, Commission v. Luxembourg and Belgium (n. 24) (emphasis added). 
interpret the provisions of the envisaged European Environment Agency (EEA) Agreement and the corresponding Treaty provisions in the same fashion, in spite of the fact that they were identically worded. The reason was that, whilst ' $[\mathrm{t}]$ he EEA is to be established on the basis of an international treaty which, essentially, merely creates rights and obligations as between the contracting parties and provides for no transfer of sovereign rights to the inter-governmental institutions which it sets up', the Treaties, 'albeit concluded in the form of an international agreement, nonetheless constitut[e] the constitutional charter of a [Union] based on the rule of law' ${ }^{26}$ Outside the context of agreements binding upon the EU and the Member States, the Court refers, where appropriate, to the autonomous nature of the EU legal order when explaining why an EU law concept does not necessarily have the same meaning as that stemming from international law or from the law of the Member States. ${ }^{27}$

\section{b) An Example: The EU System of Fundamental Rights Protection}

Turning now to the important issue of fundamental rights protection, the Court of Justice observed, in Opinion 2/13, that ' $\mathrm{t}] \mathrm{h}$ he autonomy enjoyed by EU law in relation to the laws of the Member States and in relation to international law requires that the interpretation of [the] fundamental rights [recognised by the Charter] be ensured within the framework of the structure and objectives of the EU'. ${ }^{28}$ Indeed, because of that framework, the EU system of judicial protection of fundamental rights operates in a different fashion from that of international systems of protection, such as the European Convention on Human Rights (ECHR). Although both the ECHR and the EU legal order are committed to protecting fundamental rights, their respective systems of protection do not operate in the same way. Whilst the ECHR operates as an external check on the obligations imposed by that international agreement on the contracting parties, the EU system of fundamental rights protection is an internal component of the

26 CJEU, First Opinion on the EEA Agreement, Opinion 1/91 of 14 December 1991, EU: C:1991:490, paras 20 and 21. See also CJEU, Leyla Demirkan v. Bundesrepublik Deutschland, judgment of 24 September 2013, case no. C-221/11, EU:C:2013:583.

27 See for a recent example, on the concept of 'archives' of the EU institutions which is used, in particular, in Article 2 of Protocol (No 7) on the privileges and immunities of the European Union, annexed to the EU and FEU Treaties [2016] OJ C 202/266, CJEU, Commission v. Slovenia (Archives of the ECB), judgment of 17 December 2020, case no. C-316/19, EU:C:2020:1030, para. 68.

28 CJEU, Accession of the European Union to the ECHR (n. 1), para. 170. 
rule of law within the EU. ${ }^{29}$ That distinction can be seen clearly in $X C$ and Others. ${ }^{30}$

In that case, Austrian legislation provided for a judicial remedy that allowed for criminal proceedings closed by means of a final decision to be reheard in the event of a violation of the ECHR. That remedy was applicable where the ECtHR had issued a ruling finding that Austria had committed such a violation. In addition, the same applied where it was the Austrian Supreme Court itself that made that finding, provided that the conditions of admissibility set out in the ECHR were met, notably that concerning the exhaustion of domestic remedies. ${ }^{31}$ However, the judicial remedy at issue did not apply where the final decision was adopted in breach of EU law, and in particular of the Charter of Fundamental Rights of the EU (the 'Charter'). Thus, the question that arose was whether, in order for that remedy to comply with the principles of equivalence and effectiveness, its scope had to be expanded so as to include infringements of EU law.

As to the principle of equivalence, the Court of Justice examined whether the judicial remedy at issue was, in the light of its purpose and cause of action, similar to those that seek to safeguard the rights that EU law confers on individuals. ${ }^{32}$ On the one hand, the Court of Justice described the main features of the remedy at issue in the main proceedings. It pointed out that that remedy was functionally linked to proceedings before the European Court of Human Rights (ECtHR). ${ }^{33}$ It sought to implement the rulings of the ECtHR in the Austrian legal order. In addition, it aimed to anticipate situations where the ECtHR would find that Austria had breached the ECHR. That was the reason why reliance on the remedy at issue was made conditional upon complying with the admissibility requirements set out in the ECHR. ${ }^{34}$

On the other hand, the Court of Justice provided an overview of the constitutional framework within which judicial remedies that seek to protect EU rights operate. First, by virtue of the principle of primacy, measures that are incompatible with fundamental rights recognised in the Charter cannot form part of the EU legal order. ${ }^{35}$ Second, the EU system of judicial protec-

29 Koen Lenaerts, 'The ECtHR and the CJEU: Creating Synergies in the Field of Fundamental Rights Protection', speech delivered on the occasion of the Opening of the Judicial Year at the ECtHR, 26 January 2018, Strasbourg. An article based on that speech was published in Il Diritto dell'Unione Europea (2018), 9-22.

30 CJEU, XC and Others, judgment of 24 October 2018, case no. C-234/17, EU: C:2018:853.

31 See Article 35 ECHR.

32 CJEU, $X C$ and Others (n. 30), para. 27.

33 CJEU, $X C$ and Others (n. 30), para. 31.

34 CJEU, $X C$ and Others (n. 30), para. 34.

35 CJEU, $X C$ and Others (n. 30), para. 37. 
tion entrusts national courts with responsibility for protecting effectively the rights that EU law confers on individuals. To that end, those courts may and, where appropriate, must engage in a dialogue with the Court of Justice, by means of the preliminary reference mechanism. ${ }^{36}$ That mechanism has the object of securing uniform interpretation of EU law, thereby serving to ensure its consistency, its full effect and its autonomy as well as, ultimately, the particular nature of the law established by the Treaties. Third and last, national courts called upon to apply provisions of EU law are under a duty to give full effect to those provisions, if necessary refusing of their own motion to apply any conflicting provision of national law, and without requesting or awaiting the prior setting aside of that provision of national law by legislative or other constitutional means. ${ }^{37}$ Accordingly, the Court of Justice reached the conclusion that the remedy at issue and those that seek to protect the rights that EU law confers on individuals were not similar, given that the EU 'constitutional framework guarantees everyone the opportunity to obtain the effective protection of rights conferred by the EU legal order even before there is a national decision with the force of res judicata'. ${ }^{38}$

As to the principle of effectiveness, the Court of Justice recalled its previous case law on the principle of res judicata. In that regard, it held that EU law does not require a national court automatically to go back on a judgment having the authority of res judicata in order to take into account the interpretation of a relevant provision of EU law adopted by the Court of Justice after delivery of that judgment. Given that no element of the file called into question the effective protection of the rights of the applicants in the main proceedings, the Court ruled that the principle of effectiveness did not preclude a limitation of the scope of the remedy at issue to a violation of the ECHR. In any event, the Court of Justice added that, where a final decision is adopted in breach of EU law, applicants can still seek damages against the defaulting Member State in accordance with the Köbler line of case law. ${ }^{39}$

The judgment of the Court of Justice in $X C$ and Others is an important development of the case law in the field of fundamental rights. By highlighting the autonomous nature of EU law, the Court of Justice sends the message that the EU system of fundamental rights protection, which is different from that of the ECHR, is part of the rule of law upheld through the mechanisms of effective judicial protection inherent in the EU legal order. ${ }^{40}$

36 CJEU, $X C$ and Others (n. 30), paras 40 and 41.

37 CJEU, $X C$ and Others (n. 30), para. 44.

38 CJEU, $X C$ and Others (n. 30), para. 46.

39 CJEU, $X C$ and Others (n. 30), paras 54, 55 and 58.

40 Zsófia Varga, 'Retrial and Principles of Effectiveness and Equivalence in Case of Violation of the ECHR and of the Charter: XC', CML Rev. 56 (2019), 1673-1696. 


\section{EU Law Is However Open to International Law}

However, the emphasis that the Court of Justice places on autonomy cannot be read as an attempt to cut the EU loose from its international law origins entirely; autonomy must not be confused with complete detachment. In van Gend en Loos and the cases that followed, the Court strives to define the EU constitutional space, but without denying the fact that EU law influences, and is influenced by, the legal orders that surround it. ${ }^{41}$ Indeed, as Article 3 (5) Treaty on the European Union (TEU) expressly states, the EU and thus, the Court of Justice - must contribute to 'the strict observance and the development of international law'. ${ }^{4}$

For example, when called upon to interpret international agreements to which the EU is a contracting party, the Court of Justice will interpret those agreements in a manner consistent with international law. ${ }^{43}$ In Front Polisario ${ }^{44}$ the Court was asked to interpret the expression 'territory of the Kingdom of Morocco' contained in the EU-Morocco Liberalisation Agreement (the 'Liberalisation Agreement'), so as to determine whether that agreement applied to the territory of Western Sahara. Taking account of the principle of self-determination, the rule codified in Article 29 of the Vienna Convention and the principle of the relative effect of treaties, the Court of Justice replied in the negative. Notably, drawing on several resolutions of the United $\mathrm{Na}$ tions (UN) General Assembly and on the Advisory Opinion of the International Court of Justice (ICJ) on Western Sahara, the Court observed that, since the indigenous population of Western Sahara is entitled to exercise its right to self-determination, international law accords to the territory of Western Sahara a separate and distinct status. Thus, in accordance with that principle, the expression 'territory of the Kingdom of Morocco' could not be

41 See Jiř́ Malenovský, 'La contribution ambivalente de la Cour de justice de l'Union européenne à la saga centenaire de la domestication du droit international public' in: Vincent Kronenberger, Maria Teresa D'Alessio and Valerio Placco (eds), De Rome à Lisbonne: les juridictions de l'Union à la croisée des chemins, Mélanges en l'honneur de Paolo Mengozzi (Brussels: Bruylant, 2013), 25-60.

42 See CJEU, Organisation juive européenne and Vignoble Psagot, judgment of 12 November 2019, case no. C-363/18, EU:C:2019:954, para. 48.

43 See, also, CJEU, Brita, judgment of 25 February 2010, case no. C-386/08, EU:C:2010:91, paras 40-43 (concerning the EC-Israel Association Agreement); CJEU, Western Sabara Campaign UK, judgment of 27 February 2018, case no. C-266/16, EU:C:2018:118, para. 58 (concerning the EC-Morocco Fisheries Partnership Agreement), and CJEU, Bosphorus Queen Shipping, judgment of 11 July 2018, case no. C-15/17, EU:C:2018:557, para. 67 (concerning the Montego Bay Convention).

44 CJEU, Council v. Front Polisario, judgment of 21 December 2016, case no. C-104/16 P, EU:C:2016:973. 
interpreted as including the territory of Western Sahara within the geographical scope of the Liberalisation Agreement.

Similarly, the Court of Justice has interpreted other types of secondary EU law and even the Treaties in the light of international law. ${ }^{45}$ In Wightman and Others, for example, the question was whether Article 50 TEU could be interpreted as meaning that a Member State may revoke unilaterally the notification of its intention to withdraw from the EU for as long as a withdrawal agreement has not entered into force or, if no such agreement has been concluded, for as long as the two-year period, and any possible extension, has not expired. The Court of Justice replied in the affirmative. At the outset, it observed that, since the wording of Article 50 TEU does not explicitly address the subject of revocation, that provision had to be interpreted by examining the normative context surrounding it and the objectives it pursues. After examining the procedure to be followed if a Member State decides to withdraw from the EU, the Court of Justice found that Article 50 TEU pursues two objectives, namely, first, that of enshrining the sovereign right of a Member State to withdraw from the EU and, second, that of establishing a procedure to enable such a withdrawal to take place in an orderly fashion. It thus held that the sovereign nature of the right of withdrawal supports the conclusion that the Member State concerned has a right to revoke unilaterally the notification of its intention to withdraw from the $\mathrm{EU}$, provided that that revocation is notified in due time. Most importantly for present purposes, '[t]hat conclusion', the Court of Justice held, 'is corroborated by the provisions of the Vienna Convention, which was taken into account in the preparatory work for the Treaty establishing a Constitution for Europe'. ${ }^{46}$ As pointed out by Advocate General Campos Sánchez-Bordona, the withdrawal clause contained in Article $50 \mathrm{TEU}$, which has its origins in the Treaty establishing a Constitution for Europe, was drafted taking into account the Vienna Convention - in particular its Article 68 which 'allows for the revocability of withdrawal notifications at any time before the withdrawal takes effect'. ${ }^{47}$

45 As to primary EU law, see CJEU, Burgoa, judgment of 14 October 1980, case no. C-812/ 79, EU:C:1980:231, para. 8, and CJEU, Commission v. Slovakia, judgment of 15 September 2011, case no. C-264/09, EU:C:2011:580, para. 41. Regarding secondary EU law other than international agreements, see CJEU, Organisation juive européenne and Vignoble Psagot (n. 42).

46 CJEU, Wightman and Others (n. 22), para. 70.

47 Opinion of Advocate General Campos Sánchez-Bordona in Wightman and Others, C621/18, EU:C:2018:978, point 108. 


\section{What EU Law Is}

Expressed positively, the autonomy of the EU legal order focuses on the fact that the EU legal system operates as a self-referential system of norms that is both coherent and complete. As mentioned above, in Opinion 2/13 the Court of Justice undertook what is probably the most detailed and comprehensive analysis of that autonomy. ${ }^{48} \mathrm{By}$ giving concrete expression to the relevant passages of van Gend en Loos and Costa v. ENEL, ${ }^{49}$ the Court explained that the concept of 'autonomy' relates to the constitutional framework of the EU, ${ }^{50}$ the nature of EU law, ${ }^{51}$ the principle of mutual trust between the Member States, ${ }^{52}$ the system of fundamental rights protection provided for by the Charter, ${ }^{53}$ the substantive law of the EU that directly contributes to the implementation of the process of European integration, ${ }^{54}$ the principle of sincere cooperation, ${ }^{55}$ and the EU system of judicial protection of which the preliminary reference procedure laid down in Article 267 Treaty on the Functioning of the European Union (TFEU) is the keystone. ${ }^{56}$

One may draw six distinct conclusions from this understanding of autonomy, which demonstrate that it has purposive, substantive and institutional dimensions. ${ }^{57}$

48 CJEU, Accession of the European Union to the ECHR (n. 1).

49 CJEU, Accession of the European Union to the ECHR (n. 1), paras 157-177.

50 CJEU, Accession of the European Union to the ECHR (n. 1), para. 165 (referring to the principle of conferral and to the institutional framework of the EU).

51 CJEU, Accession of the European Union to the ECHR (n. 1), para. 166 (referring to the principles of primacy and direct effect).

52 CJEU, Accession of the European Union to the ECHR (n. 1), paras 167 and 168.

53 CJEU, Accession of the European Union to the ECHR (n. 1), paras 169-171.

54 CJEU, Accession of the European Union to the ECHR (n. 1), para. 172 (referring to the Treaty provisions 'providing for the free movement of goods, services, capital and persons, citizenship of the Union, the area of freedom, security and justice, and competition policy').

55 CJEU, Accession of the European Union to the ECHR (n. 1), para. 173.

56 CJEU, Accession of the European Union to the ECHR (n. 1), paras 174-176.

57 See, in this regard, Shuibhne (n. 17), 14-19. The first dimension relates to the 'particular aims and objectives of the [EU]' such as the sharing of common values (Article 2 TEU) that gives rise to mutual trust between the Member States. The second dimension focuses on the substantive norms of the EU that are integral to the autonomy of the EU legal order, such as fundamental rights. The third dimension looks at the allocation of powers provided for by the Treaties, the respect of which is guaranteed by the Court of Justice. 


\section{The Incorporation of External Norms Into the EU Legal Order}

It is the Treaties themselves that determine whether a norm forms part of the EU legal order. Whilst the EU legal order is - as mentioned above - open to external influences, those influences may not call into question the constitutional tenets on which the EU is founded. This means, in essence, that the incorporation of external norms into EU law is made conditional upon those norms complying with the fundamental values and structures on which the EU is founded. ${ }^{58}$ If those norms fail to comply with those values and structures, then they cannot form part of EU law. ${ }^{59}$

The Kadi $I$ and $I I$ judgments demonstrate that an international law obligation - even if it is imposed by the UN Security Council - may be incorporated into the EU legal order, and thus be implemented by the EU or its Member States, only if that obligation complies with the values of liberty, democracy and respect for fundamental rights as recognised in the Charter, which all form part of the EU's 'foundation'.60 Contrary to what some scholars posited when those judgments were delivered, ${ }^{61}$ such a limitation on the incorporation of international law obligations does not call into question the EU's commitment to international law in general, and to effective multilateralism in particular. On the contrary, that limitation has had a positive effect on the UN Security Council sanctions regime, since it triggered re-

58 See CJEU, Opinion 1/00 (Agreement on the establishment of a European Common Aviation Area) of 18 April 2002, case no. EU:C:2002:231, paras 21, 23 and 26; CJEU, Agreement creating a Unified Patent Litigation System, Opinion 1/09 of 8 March 2011, case no. EU: C:2011:123, para. 76, and CJEU, Accession of the European Union to the ECHR (n. 1), para. 183. In the field of external relations, Cremona observes that autonomy is, first and foremost, a systemic structural principle that is 'concerned with the operation of the system as a whole, with building the EU's identity as a coherent, effective and autonomous actor in the world'. Marise Cremona, 'Structural Principles and Their Role in EU External Relations Law', Current Legal Probs. 69 (2016), 35-66 (52).

59 For a similar reading of autonomy, see Eileen Denza (n. 20), 196 (positing that the Court of Justice has complied with its mandate of upholding the rule of law within the EU when '[delineating] the relationship between international and [EU] law').

60 CJEU, Kadi and Al Barakaat International Foundation v. Council and Commission, judgment of 3 September 2008, joined cases nos C-402/05 P and C-415/05 P, EU:C:2008:461, para. 303, and CJEU, Commission and Others v. Kadi of 18 July 2013, joined cases nos C-584/ 10 P, C-593/10 P and C-595/10 P, EU:C:2013:518. See, for an analysis of Kadi I from the perspective of autonomy, Inge Govaere, 'The Importance of International Developments in the Case Law of the European Court of Justice: Kadi and the Autonomy of the EC Legal Order' in: Mary Hiscock and William van Caenegem (eds), The Internationalisation of Law (Cheltenham: Edward Elgar Publishing, 2010), 187-201.

61 See, for example, Gráinne de Búrca, 'The European Court of Justice and the International Legal Order After Kadi’, Harv. Int'l L. J. 51 (2010), 1-50. 
forms that sought to improve fundamental rights' protection in the UN system, thereby facilitating their implementation, be it at EU or national level. ${ }^{62}$ Thus, whilst some scholars described the Kadi $I$ and $I I$ judgments as 'defensive', ${ }^{63}$ the fact remains that their effect was not only to consolidate the EU constitutional framework but also to enhance a human rights culture in the wider world. ${ }^{64}$ Such positive effect is also being triggered by Opinion 1/15, where the Court of Justice held that the EU and a third country (Canada) may only enter into an international agreement that limits the fundamental rights to privacy and data protection, if those limitations are in keeping with the level of protection provided for by EU law. 65 Accordingly, the Court ruled that 'the transfer of personal data [...] from the [EU] to a non-member country is lawful only if there are rules in that country which ensure a level of protection of fundamental rights and freedoms that is essentially equivalent to that guaranteed within the [EU]'. ${ }^{66}$ Autonomy thus closes down the space for political compromise where EU fundamental rights are at stake, whilst showing the way forward if an agreement is to be reached.

In the same way, it follows from Opinion 1/09, Achmea and Opinion 1/17 that neither the EU nor the Member States may enter into an international agreement the effect of which would be to compromise the judicial dialogue between the Court of Justice and national courts or, more generally, to alter the functioning of the EU in accordance with its constitutional framework. ${ }^{67}$

In Opinion 1/09,68 the Court of Justice held that the draft agreement creating a Unified Patent Litigation System was not compatible with EU law,

62 Denza (n. 20), 185.

63 See de Witte (n. 18), 81.

64 See, e.g., Devika Hovell, 'Kadi: King-Slayer or King-Maker? The Shifting Allocation of Decision-Making Power between the UN Security Council and Courts', M.L.R. 79 (2016), 147-182 (148) (who rightly points out that 'the Kadi litigation was a game-changer [...] In practical terms, the Kadi case was undoubtedly the single most important factor in persuading the Security Council finally to undertake meaningful procedural reform, with the establishment of the Office of the UN Ombudsperson').

65 CJEU, EU-Canada PNR Agreement, Opinion 1/15 of 26 July 2017, case no. EU: C:2017:592.

66 CJEU, EU-Canada PNR Agreement (n. 65), para. 93. See CJEU, Facebook Ireland and Schrems, judgment of 6 October 2015, case no. C-362/14, EU:C:2015:650, paras 68 and 74, and CJEU, Facebook Ireland and Schrems, judgment of 16 July 2020, case no. C-311/18, EU: C:2020:559.

67 See CJEU, Agreement creating a Unified Patent Litigation System (n. 58); CJEU, Achmea, judgment of 6 March 2018, case no. C-284/16, EU:C:2018:158, and CJEU, EU-Canada CET Agreement (n. 2).

68 CJEU, Agreement creating a Unified Patent Litigation System (n. 58). See on that Opinion, Stanislas Adam, 'Le mécanisme préjudiciel, limite fonctionnelle à la compétence externe de l’Union: note sur l'avis 1/09 de la Cour de justice', C. D. E. 47 (2011) 277-302. 
given that it conferred on an international court - which was outside the institutional and judicial framework of the EU - exclusive jurisdiction to hear a significant number of actions brought by individuals in the field of the Union patent and to interpret and apply EU law in that field. That exclusive jurisdiction meant that national courts would be deprived of their powers in relation to the interpretation and application of the relevant provisions of EU law concerning patents and the Court of Justice of its powers to reply, by preliminary ruling, to questions referred by those courts. Accordingly, the Court of Justice ruled that the EU could not ratify the agreement as drafted, since that agreement would alter the essential character of the powers which the Treaties confer on the institutions of the EU and on the Member States. More generally, it stressed the fact that all international agreements to which the EU becomes a party must ensure compliance with 'the system set up by Article 267 TFEU [which] establishes between the [Court of Justice] and the national courts direct cooperation as part of which the latter are closely involved in the correct application and uniform interpretation of [EU] law and also in the protection of individual rights conferred by that legal order'. ${ }^{9}$ Indeed, 'the tasks attributed to the national courts and to the [Court of Justice] respectively are indispensable to the preservation of the very nature of the law established by the Treaties'. ${ }^{70}$

In Achmea,${ }^{71}$ the Court of Justice held that the autonomy of the EU legal order precludes an international agreement entered into by the Member States the effect of which would be to remove from the jurisdiction of national courts - and thus from the scope of the preliminary reference procedure - disputes that may involve the application and interpretation of EU law. That case concerned the application of an arbitration clause set out in a Bilateral Investment Treaty (BIT) concluded between two Member States, i. e. the Netherlands and the Slovak Republic (as a successor State to the Czech and Slovak Federative Republic). Such an arbitration clause entitled an investor from one of those two Member States, in the event of a dispute concerning investments in the other Member State, to bring proceedings against the latter Member State before an arbitral tribunal whose jurisdiction that Member State has undertaken to accept.

At the outset, the Court of Justice noted that, although the arbitral tribunal was only called upon to rule on possible infringements of the BIT, in order for that tribunal to do so it had to take account of the law applicable in the contracting party where the investment was made, including national, EU,

69 CJEU, Agreement creating a Unified Patent Litigation System (n. 58), para. 84.

70 CJEU, Agreement creating a Unified Patent Litigation System (n. 58), para. 85.

71 CJEU, Achmea (n. 67). 
and international law. This meant that the arbitral tribunal could be called upon to interpret and apply rules and principles of EU law, in particular the freedom of establishment and the free movement of capital. Next, the Court of Justice observed that the arbitral tribunal did not form part of the EU judicial system, since the very raison d'être of the arbitration clause contained in the BIT at issue was precisely to prevent investor-related disputes from being submitted to the courts of the contracting parties. As a result, that tribunal could not be classified as a court or tribunal 'of a Member State' within the meaning of Article 267 TFEU. Moreover, the arbitral award was final and the question whether that award was subject to review by a court of a Member State - thereby ensuring the potential application of the preliminary reference mechanism - had to be examined in the light of the law of the country chosen as the place of arbitration. For the case at hand, that country was Germany, whose law only provided for limited review of arbitral awards. Accordingly, the Court of Justice ruled that the arbitration proceedings mentioned in that BIT 'derive from a treaty by which Member States agree to remove from the jurisdiction of their own courts, and hence from the [EU] system of judicial remedies [...] disputes which may concern the application or interpretation of EU law'. Such removal 'could prevent those disputes from being resolved in a manner that ensures the full effectiveness of EU law, even though they might concern the interpretation or application of that law'. ${ }^{72}$ Accordingly, the Court of Justice ruled that the arbitration clause set out in the BIT had an adverse effect on the autonomy of the EU legal order. As a result of that judgment, 23 Member States entered into an international agreement for the termination of intra-EU BITs. ${ }^{73}$

The question that arose in the aftermath of Achmea was whether the same findings would apply in relation to 'extra-EU BITs', i. e. entered into by a third country, on the one hand, and the EU and its Member States, on the other hand. ${ }^{74}$ The Court of Justice addressed that question in Opinion 1/17.

72 CJEU, Achmea (n. 67), para. 55.

73 Agreement for the termination of Bilateral Investment Treaties between the Member States of the European Union, OJ 2020 L 169/1. Sweden, Austria, Finland, and Ireland are not parties to that agreement. However, by the time that agreement was signed, Ireland had already terminated the intra-EU BITs to which it was a contracting party. See Panos Koutrakos, 'The Gift that Keeps on Giving - Autonomy, Investor Protection and the Termination of Intra-EU Bilateral Investment Treaties', E. L. Rev. 45 (2020), 597-598. It is worth noting that Article 14 of the agreement constitutes 'a special agreement' within the meaning of Article 273 TFEU: paragraph 2 of Article 14 states that 'if a dispute between the contracting parties cannot be settled amicably within 90 days, the dispute shall, on the request of one of the contracting parties to the dispute, be submitted to the [Court of Justice]'.

74 Panos Koutrakos, 'The Autonomy of EU Law and International Investment Arbitration', Nord. J. Int'l L. 88 (2019), 41-64 (who correctly points out that the rationale underpinning Achmea does not apply to extra-EU BITs, since the Court of Justice 'places emphasis on 
It ruled, in essence, that the mechanism for settling disputes between investors and States contained in the 'Comprehensive Economic and Trade Agreement' (CETA) entered into by Canada, on the one hand, and the EU and its Member States, on the other hand, did not adversely affect the autonomy of the EU legal order. That mechanism envisaged the creation of a Tribunal and an Appellate Tribunal (the 'envisaged tribunals') and, in the longer term, a multilateral investment tribunal. Thus, CETA was a first stage in the establishment of an 'Investment Court System' (ICS).

First, the Court of Justice found that, just as was the case for the international court at issue in Opinion 1/09 and the arbitration tribunal in Achmea, the envisaged tribunals were outside the EU judicial system. ${ }^{75}$ However, the mechanism laid down in CETA did not compromise the judicial dialogue between the Court of Justice and national courts, since the envisaged tribunals lacked jurisdiction to interpret or apply EU law other than that which related to the provisions of CETA. ${ }^{76}$ In particular, those tribunals could not determine the legality of a measure alleged to constitute a breach of CETA under the 'domestic law of one of the Parties', including EU law (other than CETA).$^{77}$ Moreover, questions pertaining to the interpretation or application of EU law (again, other than CETA) were to be treated as 'a matter of fact' and the interpretation of that law made by the Court of Justice was binding upon those tribunals. Conversely, neither the Court of Justice nor national courts were to be bound by the meaning given to their own 'domestic' law by those tribunals. ${ }^{78}$ Those findings also explained why CETA did not make any provision for the prior involvement of the Court of Justice that would permit or even oblige the envisaged tribunals to make a reference for a preliminary ruling to that Court. ${ }^{79}$ The Court distinguished that disputesettlement mechanism, in particular, from the Unified Patent Litigation System examined in Opinion 1/09.80 As explained above, the draft agreement creating that Unified Patent Litigation System conferred upon an international court external to the EU judicial system jurisdiction to settle disputes involving individuals and to apply in that context, as a matter of law, not only

the constitutionalized setting within which relations between Member States are regulated under EU law').

75 CJEU, EU-Canada CET Agreement (n. 2), para. 118.

76 See, in this regard, Cécile Rapoport, 'Balancing on a Tightrope: Opinion 1/17 and the ECJ's Narrow and Tortuous Path for Compatibility of the EU's Investment Court System (ICS)', CML Rev. 51 (2020), 1725-1772 (1749-1750), who stresses the fact that CETA did not aim at 'extending a part of the EU law acquis to Canada'.

77 CJEU, EU-Canada CET Agreement (n. 2), para. 121.

78 CJEU, EU-Canada CET Agreement (n. 2), para. 131.

79 CJEU, EU-Canada CET Agreement (n. 2), para. 134.

80 CJEU, EU-Canada CET Agreement (n. 2), paras 123-125. 
that agreement but also other EU acts or rules. That agreement thus 'displaced' the jurisdiction of national courts on disputes concerning EU law. That was such as to call into question the integrity of EU law because it precluded those courts from entering into dialogue with the Court of Justice through the preliminary ruling procedure which, as we have seen, is the 'keystone' of the EU judicial system.

Second, the Court of Justice decided that the provisions of CETA did not alter the allocation of competences resulting from the Treaties. This was because, prior to instituting proceedings before the envisaged tribunals, a Canadian investor is required to deliver to the EU 'a notice requesting a determination of the respondent', identifying the measures in respect of which the investor intends to submit a claim. The EU is then required to inform that investor 'whether the [EU] or a Member State [...] [is to] be the respondent'. ${ }^{81}$ Accordingly, it is for the EU itself to decide whether a dispute brought by a Canadian investor falls within the scope of its own competences or remains exclusively within the purview of the Member States. In that regard, it is important to highlight the distinction between the arrangements provided by CETA and the co-defendant mechanism set out in the draft agreement on the Accession of the EU to the ECHR. As the Court of Justice explained in Opinion 2/13, where the EU or a Member State requested leave to intervene as co-respondent in a case brought before the ECtHR, the latter court would have had the final say as to whether the alleged breach of the ECHR in question was attributable to a Member State, to the EU or to both. ${ }^{82}$ That co-defendant mechanism could have potentially distorted the principle of conferral, in general, and the effectiveness of Article 51 (1) of the Charter, in particular. ${ }^{83}$

Third and last, the Court of Justice found that the mechanism laid down in CETA did not encroach upon the prerogatives of the EU legislator: that agreement, together with its Joint Interpretation Instrument, made it clear that it was not for the envisaged tribunals to adjudicate on the level of protection of a public interest that led to the introduction by the EU legislator of regulatory restrictions in the sphere of the internal market. In the light of the principle of democracy on which the functioning of the EU

81 See Article 8.21 CETA.

82 CJEU, Accession of the European Union to the ECHR (n. 1), paras 223-225.

83 Article 51(1) of the Charter states that ' $[t]$ he provisions of this Charter are addressed to the institutions, bodies, offices and agencies of the Union with due regard for the principle of subsidiarity and to the Member States only when they are implementing Union law. They shall therefore respect the rights, observe the principles and promote the application thereof in accordance with their respective powers and respecting the limits of the powers of the Union as conferred on it in the Treaties.' 
is founded, as was already emphasised in Kadi $I,{ }^{84}$ that was a decision for the EU legislator alone to take..$^{85}$ In that regard, Opinion 1/17 sheds light on the status of representative democracy as an essential 'pillar' of the EU's constitutional framework and, consequently, of the autonomy of its legal order. That approach, which highlights a functional understanding of autonomy of the EU legal order but from a different perspective, was confirmed in Junqueras Vies, ${ }^{86}$ a case concerning the scope of the immunity which EU citizens elected as Members of the European Parliament enjoy and which protects them, in particular, from criminal proceedings in the Member States. ${ }^{87}$ In that landmark judgment, the Court expressed similar concerns with regard to external encroachments - although in this case by the Member States - on the functioning of the EU as a democratic political system. ${ }^{88}$

Opinion 1/17 thus indicates that, in principle, the EU can enter into international agreements conferring upon courts or arbitration bodies that are outside the EU judicial system jurisdiction to settle disputes concerning alleged violations of that agreement by the EU or by a Member State, and therefore to apply such agreements 'as a matter of law' in order to award damages. This is not called into question by the jurisdiction of the Court of

84 CJEU, Kadi I (n. 60), para. 303. See also, more recently, CJEU, Puppinck and Others v. Commission, judgment of 19 December 2019, case no. C-418/18 P, EU:C:2019:1113, para. 64, a case in which the Court dealt with a citizens' initiative within the meaning of Regulation (EU) No. 211/2011 of the European Parliament and of the Council of 16 February 2011 on the citizens' initiative OJ 2011 L 65/1.

85 As can be inferred from para. 148 in limine of Opinion 1/17, however, that is without prejudice to the possibility for the EU, within the scope of its competences, to negotiate harmonisation of such levels of protection with third countries. Such harmonisation by no means undermines the functioning of the EU as a democratic political system because an international commitment of the EU to that effect is subject to the consent of the European Parliament [Art. 218 (6), first subparagraph, a), TFEU]. Indeed, it is not comparable to a situation in which a (quasi-)judicial organ external to the EU judicial system were allowed to call into question levels of protection resulting from a democratic choice made by the EU and reflected in secondary EU law. It follows that, as Neframi correctly put it, 'the EU standards of protection of [a] public interest do not, as such, fall under the principle of autonomy', see Neframi (n. 3), 44.

86 CJEU, Junqueras Vies, judgment of 19 December 2019, case no. C-502/19, EU: C:2019:1115, para. 63 .

87 The main proceedings concerned in essence a Spanish politician elected as a member of the European Parliament but who was precluded from exercising that political mandate because, before the first session following the election of MEPs, he was prosecuted by Spanish authorities for his participation in Catalonia's secessionist process and allegedly committed, in that context, acts of 'rebellion' or 'sedition', 'civil disobedience' and 'misappropriation of funds', all of which are criminal offences under Spanish law.

88 See, on that analogy between Opinion 1/17 and the judgment in Junqueras Vies, Lenaerts, (n. 3), 303-304. 
Justice to interpret such agreements as an integral part of the EU's legal order. ${ }^{89}$ Indeed, 'the jurisdiction of the courts and tribunals specified in Article 19 TEU to interpret and apply those agreements does not take precedence over either the jurisdiction of the courts and tribunals of the non-Member States with which those agreements were concluded or that of the international courts or tribunals that are established by such agreements'. 90

As Opinion 1/91 on the first draft EEA agreement demonstrates, however, there can be situations where, on closer examination, even 'external' jurisdiction limited to the agreement itself entails the risk of undermining the EU constitutional framework. ${ }^{91}$ In a nutshell, the Court held in that landmark Opinion that a threat to the autonomy of the EU (then Community) legal order resulted from the combined effect of three characteristics of that draft agreement: first, there was a large overlap between provisions contained in that agreement and identically worded provisions in EU law, in particular rules governing the internal market and competition; second, the aim of that agreement was to ensure 'homogeneity' in the interpretation and application of those rules throughout the EEA, and third, the agreement envisaged the creation of an 'EEA Court', which would have had jurisdiction inter alia to settle disputes between the contracting parties and which would only be bound by the relevant case law of the Court of Justice pre-dating the signature of the agreement. The agreement therefore contained no guarantee that the EEA Court would follow the judgments of the Court of Justice given after that signature. Against that background, the objective of 'homogeneity' of the law throughout the EEA was such as to 'condition' future interpretation of EU law corresponding to EEA law and hence undermine the role of the Court of Justice 'to ensure that in the interpretation and application of the Treat[ies] the law is observed'. 92 That objection was addressed in a second draft EEA agreement, in which the project of creating an 'EEA Court' was abandoned and issues concerning homogeneity of the law throughout the EEA were to be resolved by a Joint Committee whose decisions may not affect the case-law of the Court of Justice. The Court

89 See CJEU, Haegeman, judgment of 30 April 1974, case no. C-181/73, EU:C:1974:41, paras 3-6, and CJEU, Western Sabara Campaign UK (n. 43), para. 46. It should be emphasised however that CETA has no direct effect in the legal systems of the Parties to it (Art. 30.6.1 of the CETA).

90 CJEU, EU-Canada CET Agreement (n. 2), para. 116 (emphasis added).

91 See already Lenaerts, (n. 3), 297-298.

92 The provision corresponding to Art. 19(1) TEU was, at the material time, Art. 164 of the EEC Treaty. See CJEU, First Opinion on the EEA Agreement (n. 26), paras 45 and 46. 
declared that new draft compatible with the principle of autonomy in Opinion $1 / 92 .{ }^{93}$

To sum up, Opinion 1/09, Achmea, and Opinion 1/17 show that 'an international agreement providing for the creation of a court responsible for the interpretation of its provisions and whose decisions are binding on the [EU], is, in principle, compatible with EU law', ${ }^{94}$ provided that such an agreement does not call into question the uniform interpretation and application of EU law by adversely affecting the dialogue between the Court of Justice and national courts and, more generally, that it does not undermine the essence of the EU's decision-making process. Opinion 1/17 shows, in particular, that there is no solid basis for arguing that autonomy is symptomatic of a general 'mistrust' of the Court of Justice vis-à-vis courts external to the EU judicial system, precluding them from dealing with any issue of EU law. The case law examined above reflects a much more nuanced conception of autonomy which - to borrow Pirker's and Reitermeyer's typology of autonomy $y^{95}$ - is neither purely 'exclusive' nor purely 'discursive'. ${ }^{96}$ In line with the 'relative flexibility' characterising the relationship between EU law and international law, ${ }^{97}$ that conception is built upon a carefully balanced compound of resilience and permeability, with the sole aim of functionally protecting the EU's constitutional framework and therefore without unduly limiting the effectiveness of the EU's external action. ${ }^{98}$ That is consistent with

93 See CJEU, Second Opinion on the EEA Agreement, Opinion 1/92 of 10 April 1992, EU: C:1992:189, paras 21-29.

94 CJEU, Accession of the European Union to the ECHR (n. 1), para. 182 and CJEU, EUCanada CET Agreement (n. 2), para. 106. See also CJEU, EEA Agreement - I, (n. 26), paras 40 and 70, and CJEU, Agreement creating a Unified Patent Litigation System, (n. 58), para. 74.

95 Benedikt H. Pirker and Stefan Reitermeyer, 'Between Discursive and Exclusive Autonomy - Opinion 2/13, the Protection of Fundamental Rights and the Autonomy of EU Law', Cambridge Yearbook of European Legal Studies (2015), 171-172. The authors describe the "exclusive" approach as one in which emphasis is primarily put on 'the co-existence of legal orders and the unhindered application of the foundational principles of each order', which results in ' $[1]$ ess trust $[\ldots]$ in other courts', whereas the "discursive" approach 'pursues a more integrationist rationale and requires courts to accept as a matter of principle that there are other courts with their own jurisdiction', and does 'not assume that other courts will misuse their powers' (Pirker and Reitermeyer (n. 95), 171).

96 See also Christian Riffel, 'The CETA Opinion of the European Court of Justice and Its Implications - Not that Selfish After All', JICL (2019), 520-521. That led an author to depict Opinion 1/17 as a sign of 'pragmatism'. See Panos Koutrakos, 'Editorial: More on Autonomy Opinion 1/17 (CETA)', E. L. Rev. 44 (2019), 293.

97 Koen Lenaerts, 'Les fondements constitutionnels de l'Union européenne dans leur rapport avec le droit international' in: La Cour de justice de l'Union européenne sous la présidence de Vassilios Skouris (2003/2015),Liber Amicorum Vassilios Skouris (Bruylant: Bruxelles, 2015), 370 .

98 See, on the latter aspect, Neframi, (n. 3), 48. 
autonomy envisaged from a transnational perspective, examined in the next section.

\section{The Transnational Dimension of Autonomy}

EU law is autonomous not only from international law but also from the laws of the Member States. However, that autonomy does not operate in the same fashion. On the one hand, the incorporation of international law into EU law is made conditional upon the former complying with the constitutional tenets of the latter. On the other hand, with respect to the Member States, autonomy implies that the incorporation of EU law into the national legal orders cannot be made conditional upon EU law complying with national law, as such compliance would call into question the very raison d'être of EU law as the law that is common to all the Member States. As the Court of Justice observed in Opinion 2/13, the autonomy of the EU legal order entails 'mutually interdependent legal relations binding the [EU] and its Member States reciprocally as well as binding the Member States to one another'. ${ }^{99}$ With respect to the Member States, that autonomy has both a supranational and a transnational dimension.

Supranationally, that autonomy requires EU law - and that law only - to determine the way in which normative conflicts are to be resolved. We will come back to that aspect of autonomy in sections III. 3. and III. 5. of this article.

Transnationally, that autonomy requires the Member States, first and foremost, to share the same degree of commitment towards the values on which the EU is founded, set out in Article 2 TEU. The autonomy of the EU legal order thus defines what it means to be a Member State of the EU, i. e. to be a member of a group of European States that have freely and sovereignly decided to join efforts in a common and ongoing quest for peace, prosperity and justice by creating a Union of values. ${ }^{100}$ From a transnational perspective, autonomy is given concrete expression by the principle of mutual trust and the principle of equality of the Member States before the law. Since the Member States are all equally committed to upholding the values on which the EU is founded, they all deserve equal justice under EU law. In the light of

99 CJEU, Accession of the European Union to the ECHR (n. 1), para. 167.

100 CJEU, Wightman and Others (n. 22), para. 65 (holding that 'given that a State cannot be forced to accede to the [EU] against its will, neither can it be forced to withdraw from the [EU] against its will'). 
that reciprocal commitment, old rivalries and mistrust no longer have a raison d'être and must be replaced by mutual respect and mutual trust.

First, as Article 4 (2) TEU states, all Member States are equal before the Treaties. All provisions of EU law are to have the same meaning and are to be applied in the same fashion throughout the EU. In our view, three direct implications flow from the principle of 'equality of the Member States before the Treaties'. First, the uniform interpretation and application of EU law are key for guaranteeing that equality. Second, the uniform interpretation of EU law may only be ensured by one court and one court only, i. e. the Court of Justice. Last but not least, only the principle of primacy may adequately ensure the uniform interpretation and application of EU law. EU law - as interpreted by the Court of Justice - is 'the supreme law of the land' as it is only that supremacy that can guarantee that normative conflicts between EU law and national law are solved in the same fashion. Primacy thus ensures that both the Member States and their citizens are equal before the law. Moreover, those three principles are deeply intertwined: one cannot exist without the two others. Without uniformity, there is no equality of the Member States before the law. Without the Court of Justice, there is no uniformity. Without primacy, there is no uniformity and thus, no equality. It is only by the judicial enforcement of the uniformity and primacy of EU law that European citizens may find equal justice under that law. Seen from a transnational perspective, the principle of primacy is not just a means of solving normative conflicts between two legal orders, but is rather, first and foremost, a grounding principle ensuring that all Member States - regardless of their size, policy views, or economic power - and their citizens are treated equally before the law. ${ }^{101}$

Second, given that all Member States are reciprocally committed to upholding the values on which the EU is founded, that reciprocal commitment requires 'each of those States, save in exceptional circumstances, to consider all the other Member States to be complying with EU law and particularly with the fundamental rights recognised by EU law'. ${ }^{102}$ It gives rise to mutual trust and makes possible the establishment and development of an area without internal frontiers where citizens may circulate freely and securely. That mutual trust means that, save in exceptional circumstances, ${ }^{103}$ each Member State must presume that the other Member States respect those values. That is inherent in the establishment of the EU and also a prerequisite for the

101 See, in this regard, Lenaerts (n. 14).

102 CJEU, Accession of the European Union to the ECHR (n. 1), para. 191.

103 See, for example, CJEU, Aranyosi et Căldăraru, judgment of 5 April 2016, joined cases nos C-404/15 and C-659/15 PPU, EU:C:2016:198, para. 77. See Koen Lenaerts, 'La vie après l'avis: Exploring the Principle of Mutual (yet not blind) Trust', CML Rev. 54 (2017), 805-840. 
realisation of the EU's objectives. ${ }^{104}$ That explains in particular why the Court, in Achmea, did not accept that 'mistrust' concerning access to an effective judicial protection becomes the premise between two or more Member States, even in the specific context of disputes between an investor and a public authority. Autonomy thus serves to draw the dividing line between the Member States and third countries, which, as the Court suggested in Opinion 1/17 to distinguish Achmea, do not necessarily share the same degree of commitment towards those values and in respect of which 'trust' therefore cannot be presumed. ${ }^{105}$ That said, the EU can enter into an international agreement with a third country that involves, for example, judicial cooperation in criminal matters, where the courts of such third country guarantee judicial protection that is equivalent to that guaranteed by the courts of the Member States. This is, for example, the case of Iceland which, like Norway, 'has a special relationship with the [EU], which goes beyond economic and commercial cooperation'. Iceland 'implements and applies the Schengen acquis [...] it is also a party to the EEA Agreement, participates in the common European asylum system and has concluded the Agreement on the surrender procedure with the [EU]'. In relation to the latter agreement, the Court of Justice observed that 'the contracting parties [...] have expressed their mutual [trust] in the structure and functioning of their legal systems and their capacity to guarantee a fair trial'. ${ }^{106} \mathrm{~A}$ joint reading of Opinion 1/17 and I.N. suggests that, whilst mutual trust cannot be presumed in the relations with third countries, the latter may gain that trust by building a special relationship with the EU and by being equally committed to the values on which the EU is founded. ${ }^{107}$

The principle of mutual trust gives impetus to the idea of legal interdependence between the EU and its Member States as well as between the Member States inter se. That is partly why in Opinion 2/13, the Court of Justice decided that the draft agreement on the Accession of the EU to the ECHR

104 Neframi, (n. 3), 41.

105 CJEU, EU-Canada CET Agreement (n. 2), para. 129 (holding that 'the principle of mutual trust, with respect to, inter alia, compliance with the right to an effective remedy before an independent tribunal, is not applicable in relations between the [EU] and a non-Member State').

106 See, in this regard, CJEU, I.N., judgment of 2 April 2020, case no. C-897/19 PPU, EU: C:2020:262, paras 44 and 77.

107 It is therefore not correct to argue that the Court's refusal to 'extend' mutual trust to third countries in Opinion 1/17 (see above at n. 2) maintains a 'waterproof' separation between the EU and international legal orders and thereby undermines the objectives of the EU on the international scene (see, for such criticism, Christophe Maubernard, 'L'avis 1/17 ou les contours de l'autonomie procédurale et substantielle de l'ordre juridique de l'Union', Revue de l'Union européenne (2019), 575). 
was not compatible with the autonomy of the EU legal order, since it would, in areas governed by EU law, systematically require a Member State to check whether another Member State has observed fundamental rights as guaranteed by the ECHR, even though EU law imposes an obligation of mutual trust between them. ${ }^{108}$

This transnational dimension of autonomy has another, more procedural implication: the Court of Justice enjoys exclusive jurisdiction to adjudicate over conflicts between the Member States involving questions of EU law. ${ }^{109}$ Article 344 TFEU provides that the Member States may not 'submit a dispute concerning the interpretation or application of the Treaties to any method of settlement other than those provided for therein'. That exclusive jurisdiction, which is a specific expression of the more general duty of loyalty resulting from Article 4(3) TEU, ${ }^{110}$ is closely intertwined with the fundamental mission of the CJEU set out in Article 19(1) TEU to ensure that in the interpretation and application of the Treaties the law is observed. It is also an expression of Member States' trust in the Court as an 'impartial umpire' for settling disputes opposing them insofar as such disputes concern the interpretation or application of EU law. In determining the scope of that exclusive jurisdiction, the Court has stressed its importance for the autonomy of the EU legal order.

In Mox-Plant, ${ }^{111}$ the Court dealt, for the very first time, with the provision of the European Community (EC) Treaty corresponding to Article 344 TFEU. ${ }^{112}$ In that case, the Commission sought to obtain a declaration from the Court that Ireland had failed to comply with that provision of primary EU law by instituting dispute-settlement proceedings against the United Kingdom before an arbitral tribunal established under the United Nations Convention on the Law of the Sea (UNCLOS) concerning a mixed oxide fuel (MOX) plant located at Sellafield. In those proceedings, Ireland argued, in essence, that the United Kingdom failed to carry out a proper assessment of the impact which the MOX plant would have on the environment. Before the Court of Justice, the Commission argued that, since Ireland had invoked in that dispute a number of EU acts, including UNCLOS (to which the EU

108 CJEU, Accession of the European Union to the ECHR (n. 1), para. 194.

109 See Koen Lenaerts, 'The Permanent Court of International Justice and the European Court of Justice: A Bridge between Past and Present based on the Rule of Law', speech delivered on the occasion of the 100th Anniversary of the Statute of the Permanent Court of International Justice, The Hague, 10 December 2020.

110 CJEU, Accession of the European Union to the ECHR (n. 1), para. 202 and case-law cited.

111 CJEU, Commission v. Ireland, judgment of 30 May 2006, case no. C-459/03, EU: C:2006:345.

112 Ex Art. 292 EC. 
is a party) and EC directives, settling that dispute required an interpretation or application of those acts. In its view, the only judicial body that enjoyed jurisdiction to settle that dispute was therefore the Court of Justice, in the context of infringement proceedings. ${ }^{113}$ Upholding the Commission's argument, the Court stressed the fact that the institution and pursuit of the proceedings concerned before the arbitral tribunal provided for by UNCLOS, following a dispute-settlement mechanism not provided for by the Treaties, involve[d] a manifest risk that the jurisdictional order laid down in the Treaties and, consequently, the autonomy of the Community [now EU] legal system may be adversely affected'. ${ }^{114}$ The Court moreover observed that there was no conflict between Ireland's obligations under UNCLOS and the Court of Justice's exclusive jurisdiction, since that convention explicitly provides that the EU system for the resolution of disputes must in principle take precedence, as between the EU Member States, over that contained in UNCLOS. ${ }^{115}$

The protective function of Article 344 TFEU regarding the transnational dimension of autonomy was again highlighted in Achmea, a case examined in section III. 1. above. Not only was the arbitration clause set out in the BIT between the Netherlands and the Slovak Republic incompatible with Article 267 TFEU, in that it displaced jurisdiction of national courts to rule on disputes concerning the application or interpretation of EU law and thus compromised the key role of the procedure for a preliminary ruling to guarantee the full effectiveness of EU law. That clause, included in a bilateral agreement between two Member States, breached Article 344 TFEU as well. That Court's reading of Article 344 TFEU in Achmea goes a step further than that made in Mox-Plant: the prohibition contained in that Article covers not only disputes between the Member States (and indeed between them and the $\mathrm{EU})$ that raise questions of EU law, ${ }^{116}$ but also situations where Member

113 Art. 259 TFEU.

114 CJEU, Commission v. Ireland (n. 111), para. 154.

115 See Article 282 UNCLOS, which states that '[if] the States Parties which are parties to a dispute concerning the interpretation or application of this Convention have agreed, through a general, regional or bilateral agreement or otherwise, that such dispute shall, at the request of any party to the dispute, be submitted to a procedure that entails a binding decision, that procedure shall apply in lieu of the procedures provided for in this Part, unless the parties to the dispute otherwise agree'.

116 See, to that effect, Accession of the European Union to the ECHR (n. 1), paras 202 and 205. As the Court of Justice made clear in Achmea, neither Article 267 TFEU nor Article 344 TFEU oppose commercial arbitration that originates in the freely expressed wishes of the parties', since it does not 'derive from a treaty by which Member States agree to remove from the jurisdiction of their own courts, and hence from the system of judicial remedies which the second subparagraph of Article 19(1) TEU requires them to establish in the fields covered by EU law'. See CJEU, Achmea (n. 67), para. 55. 
States agree to remove from the EU judicial system disputes opposing an EU citizen or a company located in the EU - in this case, an investor - and a Member State. ${ }^{117}$ That confirms the importance attached by the Court to the specific expression of autonomy and of the Member States' duty of loyal cooperation contained in Article 344 TFEU.

The picture would not be complete without mentioning the clarifications on the scope of infringement proceedings and, incidentally, of Article 344 TFEU in the recent judgment in Slovenia/Croatia. ${ }^{118}$ In those infringement proceedings, Slovenia argued that Croatia had failed to fulfil its obligations under EU law by virtue of its failure to comply with its obligations stemming from an arbitration agreement concluded between those Member States to settle a territorial dispute, and from the arbitration award adopted by the arbitral tribunal established by that agreement. In particular, Slovenia took issue with what it regarded as violations of various rules of primary and secondary EU law (including on fishing activities) which resulted from the refusal by Croatia to recognise and apply that award. The Court recalled that it lacks jurisdiction to rule on an infringement action, where the alleged infringement of EU law is ancillary to the alleged failure to comply with obligations resulting from an arbitration agreement concluded by the Member States whose subject matter falls outside the areas of EU competence. That led the Court to declare that it lacked competence to decide on Slovenia's action. First, the subject-matter of the arbitral agreement and award fell outside the areas of EU competence as it concerned a dispute on the definition of the territories falling within the sovereignty of the Member States, which is for the latter only to determine in accordance with the rules of international law. ${ }^{119}$ Second, the alleged infringements of EU law put forward by Slovenia were ancillary to that dispute since they either resulted from the alleged failure by Croatia to comply with the arbitration agreement and with the arbitration award, or were founded on the premise that the land and sea border between those two Member States was determined by that award. ${ }^{120}$ That important judgment is another illustration of the balanced, functional approach of autonomy described in section III. 1. above : the mere fact that a dispute between the Member States has incidental links with or effects on EU law does not trigger the Court's exclusive jurisdiction if the very essence of

117 In Achmea, the referring court had raised doubts in this respect, in the light of the subject matter and purpose of Article 344 TFEU.

118 CJEU, Slovenia v. Croatia, judgment of 31 January 2020, case no. C-457/18, EU: C:2020:65.

119 CJEU, Slovenia v. Croatia (n. 118), para. 105.

120 CJEU, Slovenia v. Croatia (n. 118), para. 104. 
that dispute lies outside the reach of EU law. ${ }^{121}$ That is the exact opposite of a formalistic conception of autonomy.

\section{The Principle of Direct Effect}

The autonomy of the EU legal order also implies that it is the EU law provision itself that determines whether it produces direct effect. As van Gend en Loos made clear, it is by interpreting the EU law provision in question that one may determine whether it vests rights in individuals which may be judicially enforced. Thus, the Treaties and EU legislation adopted pursuant to those Treaties are not mere 'programmatic' norms without legal effects. On the contrary, the very raison d'être of EU law is inherently linked to the creation of individual rights that are directly enforceable before national courts. For every EU right, there must be an effective judicial remedy. It is on this founding postulate that the entire EU system of judicial protection is based. ${ }^{122}$

However, in relation to directives, 'even a clear, precise and unconditional provision of a directive does not allow a national court to disapply a provision of its national law which conflicts with it, if, in doing so, an additional obligation were to be imposed on an individual'. ${ }^{123}$ A directive, which is, by its very nature, an act addressed to the Member States, may not produce horizontal direct effect. ${ }^{124}$ By contrast, the same does not hold true in respect of fundamental rights, understood as general principles of EU law or as rights recognised in the Charter. A right recognised in the Charter may produce horizontal direct effect, provided that the Charter provision in question is sufficient in itself and does not need to be further specified by other provisions of EU or national law in order to confer on individuals a

121 The Court added however that its incompetence in infringement proceedings under Article 259 TFEU was without prejudice to - in particular - the possibility for Slovenia and Croatia to submit their dispute to the Court under a special agreement pursuant to Article 273 TFEU (CJEU, Slovenia v. Croatia (n. 118), para. 109).

122 See, e. g., Koen Lenaerts, 'The Rule of Law and the Coherence of the Judicial System of the European Union', CML Rev. 44 (2007), 1625-1659.

123 CJEU, Poptareski II, judgment of 24 June 2019, case no. C-573/17, EU:C:2019:530, para. 67.

124 CJEU, Berlusconi and Others, judgment of 3 May 2005, joined cases nos C-387/02, C391/02 and C-403/02, EU:C:2005:270, paras 72 and 73; CJEU, Arcor and Others, judgment of 17 July 2008, joined cases nos C-152/07 to C-154/07, EU:C:2008:426, paras 35-44; CJEU, OSA, judgment of 27 February 2014, case no. C-351/12, EU:C:2014:110, paras 46 and 47; CJEU, Smith, judgment of 7 August 2018, case no. C-122/17, EU:C:2018:631, para. 49; and Cresco Investigation, judgment of 22 January 2019, case no. C-193/17, EU:C:2019:43, para. 73. 
right which they may rely on as such. Accordingly, such a right is unconditional and mandatory in nature, applying not only to action taken by public authorities, but also in disputes between private parties. Thus, the Court has noted that Articles 21 (non-discrimination) and 47 (right to an effective judicial protection and to a fair trial) as well as the essence of Article 31(2) (right to an annual period of paid leave) of the Charter may produce horizontal direct effect. ${ }^{125}$ Conversely, this is not the case for Article 27 of the Charter (workers' right to information and consultation within the undertaking)..$^{126}$

This again shows that the EU system of fundamental rights protection is autonomous, given that it is EU law itself that determines the horizontal application of those rights. In the EU legal order, fundamental rights are not only seen as norms whose sole purpose is to defeat the unlawful exercise of public power, but as norms that are grounded in the values on which the EU is founded. As such, they 'irradiate' the entire EU legal order, including both public and private law. ${ }^{127} \mathrm{It}$ is worth pointing out that the Bundesverfassungsgericht (Federal Constitutional Court) (BVerfG) has recognised that concrete expression of autonomy, since it did not bring about 'a significant structural shift to the detriment of the Member States competences'. ${ }^{128}$ Within the bounds of the EU legal order, the Bundesverfassungsgericht recognised that the Court of Justice, as gesetzlicher Richter, enjoys jurisdiction to determine the norms and judge-made principles that produce (horizontal) direct effect. ${ }^{129}$

125 See CJEU, Kücükdeveci, judgment of 19 January 2010, case no. C-555/07, EU: C:2010:21; CJEU, DI, judgment of 19 April 2016, case no. C-441/14, EU:C:2016:278; CJEU, Egenberger, judgment of 17 April 2018, case no. C-414/16, EU:C:2018:257; CJEU, IR, judgment of 11 September 2018, case no. C-68/17, EU:C:2018:696, CJEU, Bauer and Broßonn, judgment of 6 November 2018, joined cases nos C-569/16 and C-570/16, EU:C:2018:871, and CJEU, Max-Planck-Gesellschaft zur Förderung der Wissenschaften, judgment of 6 November 2018, case no. C-684/16, EU:C:2018:874.

126 CJEU, Association de médiation sociale, judgment of 15 January 2014, case no. C-176/ 12, EU:C:2014:2, paras 46-48.

127 See, in this regard, Mattias Kumm, 'Who is Afraid of the Total Constitution? Constitutional Rights as Principles and the Constitutionalization of Private Law', GLJ 7 (2006), 341369. See also Koen Lenaerts, 'The Horizontal Application of the Charter', Quaderni costituzionali (2020), 633-636.

128 BVerfG, Honeywell, Order of 6 July 2010 - 2 BvR 2661/06, para. 71.

129 Similarly, in the Ajos Case, the Højesteret (Danish Supreme Court) also concurred with the Bundesverfassungsgericht in that the Court of Justice enjoys exclusive jurisdiction to provide the definitive interpretation of EU law. In particular, it has the final say as to whether EU rules and principles produce (horizontal) direct effect. See Højesteret, Ajos, judgment of 6 December 2016, Case 15/2014 (First Chamber), where that Court ruled that '[the Court of Justice] has jurisdiction to rule on questions concerning the interpretation of EU law: see Article 267 TFEU. It is therefore for the [Court of Justice] to rule on whether a rule of EU law 
Moreover, the autonomy of the EU legal order also implies that it is for the Court of Justice to determine how equally ranking principles of constitutional importance are to interact with one another. Thus, in Poptawski II, ${ }^{130}$ the Court of Justice drew an important distinction between the principle of primacy and the principle of direct effect, putting to rest a long-standing academic debate. ${ }^{131}$ Whilst all EU norms enjoy primacy, not all of them produce direct effect. In the Court of Justice's own words, 'a national court's obligation to disapply a provision of its national law which is contrary to a provision of EU law, if it stems from the primacy afforded to the latter provision, is nevertheless dependent on the direct effect of that provision in the dispute pending before that court. Therefore, a national court is not required, solely on the basis of EU law, to disapply a provision of its national law which is contrary to a provision of EU law if the latter provision does not have direct effect'. ${ }^{132}$ In order to produce direct effect, an EU norm must be sufficiently clear, precise, and unconditional. Moreover, primary EU law may rule out that an EU norm may produce direct effect, as it is the case of a Framework Decision such as that at issue in Poptareski II.

has direct effect and takes precedence over a conflicting national provision, including in disputes between individuals'. For an unofficial translation of that judgment, see $<$ https://doms tol.dk>, 45. However, the Højesteret found, drawing on the travaux préparatoires of the Law on Accession, that that law did not provide for the horizontal direct effect of fundamental rights. Since the incorporation of EU law into the Danish legal order is governed by the Law on Accession (dualist incorporation), the Højesteret could not apply the judgment of the Court of Justice providing for such effect. See CJEU, DI (n. 125). For an excellent commentary on the Ajos saga, see Ulla Neergaard and Karsten Engsig Sørensen, 'Activist Infighting among Courts and Breakdown of Mutual Trust? The Danish Supreme Court, the CJEU, and the Ajos Case', YBEL 36 (2017), 275-313.

130 CJEU, Poptawski II (n. 123).

131 Prior to that judgment, academics had drawn a distinction between situations where the EU norm is sufficiently clear, precise and unconditional in order to set aside and replace the conflicting national measure at issue (in French, 'invocabilité de substitution') and situations where the EU norm is sufficiently clear in order to set aside the conflicting national measure at issue without replacing it (in French, 'invocabilité d'exclusion'). In their view, in relation to the latter situations, a conflicting provision of national law could be set aside, even if the EU law norm did not produce direct effect. See, in this regard, Opinion of Advocate General Saggio in Joined Cases Océano Grupo Editorial and Salvat Editores, C-240/98 to C-244/98, EU: C:1999:620. See, generally on this debate, Christiaan W. A. Timmermans, 'Directives: Their Effects within the National Legal Systems', CML Rev. 16 (1979), 533-555; Denys Simon, La directive européenne (Paris: Dalloz, 1997), and Sacha Prechal, 'Member State Liability and Direct Effect: What's the Difference After All?', European Business Law Review 17 (2006), 299-316 (304).

132 CJEU, Poptarwsi II (n. 123), para. 68. 


\section{The Absence of Normative Gaps}

In order for the EU legal order to be autonomous, EU law must not allow normative gaps to appear. Indeed, autonomy could hardly be achieved in a legal system that was neither coherent nor complete. In order for the EU legal order to find its own independent space between national and international law, the fragmentation that would inevitably result from constitutional and legislative gaps cannot be allowed to persist. Although the solutions adopted to fill any gaps may be inspired by the constitutional traditions common to the Member States or by international treaties, those solutions must come from within the EU legal order itself. ${ }^{133}$ Thus, the very nature of EU law requires the Court of Justice to 'find' the law ('Rechtsfindung') by fashioning general principles of law where necessary. ${ }^{134}$ Gap-filling grounded in the 'system of the Treaty', which has historically played a seminal role for the protection of fundamental rights in the EU legal order, aims to create norms that properly reflect the nature, objectives and functioning of the EU. ${ }^{135}$ This applies not only to substantive EU norms but also to the EU system of judicial protection.

In Rosneft, for example, the Court of Justice ruled that it has jurisdiction to give judgment, by way of a preliminary ruling, on the validity of an EU act adopted under the EU's common foreign and security policy (CFSP), provided that the questions referred relate to one of the following two matters. ${ }^{136}$ First, whether the CFSP act at issue complies with the constitutional principle requiring that the implementation of the CFSP does not

133 Pierre Pescatore, 'La carence du législateur communautaire et le devoir du juge' in: Gerhard Lüke, Georg R. H. Ress, and Michael R. Will (eds), Rechtsvergleichung, Europarecht und Staatenintegration: Gedächtnisschrift für Léontin - Jean Contantinesco (Köln: Heymanns Verlag, 1983), 559-580.

134 See, on the contribution of general principles inspired by the constitutional traditions common to the Member States or by international treaties to the autonomy of the EU legal order, Lucia Serena Rossi, “Autonomie constitutionnelle de l'Union européenne, droits fondamentaux et méthodes d'intégration des valeurs "externes"' in: Anastasia Iliopoulou and Lamprini Xenou (eds), La Charte des droits fondamentaux: source de renouveau constitutionnel européen? (Bruylant: Bruxelles, 2020), 57-60.

135 See, in this regard, Koen Lenaerts and José A. Gutiérrez-Fons, 'The Constitutional Allocation of Powers and General Principles of EU law', CML Rev. 47 (2010), 1629-1669 (1631).

136 Article 275 TFEU reads as follows: '[the Court of Justice] shall not have jurisdiction with respect to the provisions relating to the [CFSP] nor with respect to acts adopted on the basis of those provisions. However, the Court shall have jurisdiction to monitor compliance with Article 40 [TEU] and to rule on proceedings, brought in accordance with the conditions laid down in the fourth paragraph of Article 263 [TFEU], reviewing the legality of decisions providing for restrictive measures against natural or legal persons adopted by the Council on the basis of [the CFSP].' 
encroach upon the powers conferred on the EU institutions under the TFEU. Second, the CFSP act in question relates to restrictive measures adopted against natural or legal persons. In that latter regard, the Court noted that in the context of actions for annulment, the EU Courts enjoy jurisdiction ex ratione materiae to rule on the validity of CFSP acts that relate to restrictive measures adopted against natural or legal persons. Accordingly, it would be inconsistent with the system of effective judicial protection established by the Treaties to interpret the [relevant Treaty provision] as excluding the possibility [for national courts to make preliminary references to the Court of Justice] on the validity of [CFSP] decisions prescribing the adoption of such measures'. ${ }^{137}$

More recently, in Bank Refah Kargaran v. Council, ${ }^{138}$ the Court of Justice held that the EU Courts enjoy jurisdiction to rule on an action for damages in so far as such an action seeks to obtain compensation for the harm allegedly caused by restrictive measures taken against natural or legal persons pursuant to CFSP decisions. This is so despite the fact that the wording of Article 275 TFEU does not expressly mention an autonomous form of action of that sort. ${ }^{139}$ After recalling its previous findings in Rosneft, the Court of Justice noted that Article 215 TFEU - which contains the legal basis for the adoption of EU legislation implementing CFSP decisions imposing restrictive measures - 'serves as a bridge between the objectives of the EU Treaty in matters of the CFSP and the actions of the $[\mathrm{EU}]$ involving economic measures falling within the scope of the FEU Treaty'. ${ }^{140}$ Given that it is common ground that the EU Courts enjoy jurisdiction to rule on an action for damages seeking to obtain compensation for the harm caused by EU legislation adopted pursuant to Article 215 TFEU, ${ }^{141}$ the Court of Justice found that 'the necessary coherence of the system of judicial protection provided for by EU law requires that, in order to avoid a lacuna in the judicial protection of the natural or legal persons concerned, the [EU Courts] must also have jurisdiction to rule on the harm allegedly caused by restrictive measures provided for in CFSP [d]ecisions'. ${ }^{142}$

137 CJEU, Rosneft, judgment of 28 March 2017, case no. C-72/15, EU:C:2017:236, para. 76. 138 CJEU, Bank Refah Kargaran v. Council, judgment of 6 October 2020, case no. C-134/ 19 P, EU:C:2020:793.

139 CJEU, Bank Refah Kargaran v. Council (n. 138), para. 31.

140 CJEU, Bank Refah Kargaran v. Council (n. 138), para. 38.

141 See, in this regard, CJEU, Safa Nicu Sepahan v. Council, judgment of 30 May 2017, case no. C-45/15 P, EU:C:2017:402.

142 CJEU, Bank Refah Kargaran v. Council, (n. 138), para. 39. 


\section{Normative Conflicts and Value Diversity}

Normative conflicts between EU norms (internal conflicts) or between an EU norm and norms belonging to other legal orders (external conflicts) are to be solved in accordance with primary EU law. ${ }^{143}$ Internally, the principle of hierarchy of norms pervades EU law. ${ }^{144}$ Secondary EU law must comply with primary EU law. In the same way, EU administrative measures which are incompatible with EU legislative measures will be annulled or declared invalid. Externally, the Court of Justice has held that international treaties which have been incorporated into EU law enjoy a 'supra-legislative' status ${ }^{145}$ but, as mentioned above, may not undermine the constitutional tenets on which the EU is founded. ${ }^{146}$ Rules of national law, even those of constitutional rank, that conflict with EU law must be set aside. ${ }^{147}$ Since EU law indicates how normative conflicts are to be solved, that law establishes a coherent legal order based on the rule of law.

However, it does not follow from the fact that EU law itself determines how normative conflicts are to be solved - and, in particular, that EU law prevails over conflicting provisions of national law - that the autonomy of the EU legal order rules out value diversity. On the contrary, diversity forms part and parcel of that autonomy. In the field of fundamental rights, the case law shows that it is ultimately for the EU political process to decide whether a uniform standard of protection is to replace a plurality of national standards.

Where EU law allows room for such a plurality, national standards must comply with three cumulative conditions. First, those standards must comply with the level of protection guaranteed by the Charter. Second, national standards may only be applied where the EU has not adopted a uniform level of protection which, needless to say, must itself comply with the Charter. Last but not least, a higher level of protection provided for by national law must not jeopardise the objectives pursued by EU law.

143 Regarding external conflicts, see above sections III. 1. and III. 3.

144 See, generally, Koen Lenaerts and Piet Van Nuffel, European Union Law, (3rd edn, London: Sweet \& Maxwell, 2011), 817 et seq.

145 CJEU, The International Association of Independent Tanker Owners and Others, judgment of 3 June 2008, case no. C-308/06, EU:C:2008:312, para. 42.

146 CJEU, Kadi and Al Barakaat International Foundation v. Council and Commission (n. 60), para. 282.

147 CJEU, Costa v. ENEL (n. 11), and CJEU, Simmenthal, judgment of 9 March 1978, case no. 106/77, EU:C:1978:49. See, also CJEU, Internationale Handelsgesellschaft, judgment of 17 December 1970, case no. 11/70, EU:C:1970:114, para. 3; CJEU, Winner Wetten, judgment of 8 September 2010, case no. C-409/06, EU:C:2010:503, para. 61, and CJEU, Križan and Others, judgment of 15 January 2013, case no. C-416/10, EU:C:2013:8, para. 70. 
That point may be illustrated by highlighting the contrast between, on the one hand, the ruling of the Court of Justice in Melloni and, on the other hand, that in M.A.S. and M.B. Whilst in the first case, it was held that EU law did indeed prescribe a uniform level of fundamental rights protection, in the circumstances of the latter case the opposite conclusion was reached, leaving room for national diversity.

In Melloni, ${ }^{148}$ the EU legislator had amended, in 2009, the European Arrest Warrant Framework Decision with a view to protecting the procedural rights of persons subject to criminal proceedings whilst improving mutual recognition of judicial decisions between Member States. To that effect, the EU legislator introduced a new provision listing the circumstances under which the executing judicial authority may not refuse execution of a European Arrest Warrant issued against a person convicted in absentia. The Court of Justice noted that the new provision complied with Articles 47 and 48 of the Charter given that it only applied to situations where the person convicted in absentia was deemed to have voluntarily and unambiguously waived his or her right to be present at the trial in the issuing Member State. Since the EU legislator had itself struck, in compliance with the Charter, a balance between the protection of those fundamental rights and the requirements of mutual recognition of judicial decisions, the application of higher national standards was ruled out.

The concept of diversity was explained by the Court of Justice in M.A.S. and M.B., a Value Added Tax (VAT) case. There, the Court recalled that the Member States must ensure, in cases of serious VAT fraud, that effective and deterrent criminal penalties are adopted. Nevertheless, in the absence of EU harmonisation, it is for the Member States to adopt the rules of limitation applicable to criminal proceedings relating to those cases. This means, in essence, that whilst a Member State must impose effective and deterrent criminal penalties in cases of serious VAT fraud, it is free to consider, for example, that rules of limitation form part of substantive criminal law. Where that is the case, such a Member State must comply with the principle that criminal offences and penalties must be defined by law, a fundamental right enshrined in Article 49 of the Charter which corresponds to Article 7(1) ECHR. ${ }^{149}$ Accordingly, even where the rules of limitation at issue prevent the imposition of effective and deterrent criminal penalties in a significant number of cases of serious VAT fraud, the national court is under no obligation to disapply those rules in so far as that obligation is incompatible with

148 See CJEU, Melloni, judgment of 26 February 2013, case no. C-399/11, EU:C:2013:107.

149 See CJEU, M.A.S. and M.B., judgment of 5 December 2017, case no. C-42/17, EU: C:2017:936, para. 55 . 
Article 49 of the Charter. That does not mean, however, that those rules of limitation are left untouched to the detriment of the financial interests of the EU. In the light of the primacy, unity and effectiveness of EU law, it is however, first and foremost, for the national legislator to amend those rules of limitation so as to avoid impunity in a significant number of cases of serious VAT fraud.

It follows from those two examples that neither European unity nor national diversity is absolute, as they must both comply with the level of protection provided for by the Charter. In addition, national diversity must not jeopardise the EU integration project, since it must take due account of the primacy, unity and effectiveness of EU law.

It is worth noting that the Bundesverfassungsgericht has recognised and faithfully applied that case law in the context of two recent orders relating to the right to be forgotten. ${ }^{150}$ In one of those two parallel orders, it held that, where the German authorities apply provisions that are fully harmonised by EU law (Anwendung unionsrechtlich vollständig vereinheitlichter Regelungen), the relevant standard of protection does not stem from German fundamental rights as guaranteed by the Basic Law, but only from fundamental rights as recognised by EU law. ${ }^{151}$ In those cases, in accordance with the principle of primacy (Anwendungsvorrang), the Bundesverfassungsgericht will examine directly, in close cooperation with the Court of Justice, whether the German authorities have respected fundamental rights as recognised by EU law, that is to say by the Charter.

The case at hand concerned a request for de-referencing lodged by an employer against a search engine involving a hyperlink that led to a television programme that accused that employer of ill-treating one of her employees. The Bundesverfassungsgericht held that the Higher Regional Court of Celle (Oberlandesgericht Celle) had rightly dismissed the application,

150 BVerfG, Recht auf Vergessen I, orders of 6 November 2019, 1 BvR 16/13, and Recht auf Vergessen II, 1 BvR 276/17. See, in this regard, Mattias Wendel, 'The Two-Faced Guardian - or How One Half of the German Federal Constitutional Court Became a European Fundamental Rights Court', CML Rev. 57 (2020), 1383-1426 (1425) (holding that '[the] First Senate has assumed responsibility for the judicial observance of EU fundamental rights in Germany by accepting EU fundamental rights as a standard of constitutional review. Embracing EU fundamental rights is not only one of the most important developments of the [BVerfG] in almost 70 years of fundamental rights case law; it also opens a new chapter in the Basic Law's permeability to EU law'), and Daniel Thym, 'Friendly Takeover, or: the Power of the 'First Word'. The German Constitutional Court Embraces the Charter of Fundamental Rights as a Standard of Domestic Judicial Review', Eu Const. L. Rev. 16 (2020), 187-212 (211) (noting that '[i]n the Right to be Forgotten decisions, the [BVerfG] made an about-turn and followed other constitutional courts in embracing the Charter of Fundamental Rights as a standard of judicial review).

151 BVerfG, Recht auf Vergessen II (n. 150), para. 42. 
striking the correct balance between, on the one hand, the employer's right to a private life and, on the other hand, internet users' right to information and the television broadcasting corporation's freedom to conduct a business and freedom of expression. In balancing those fundamental rights recognised by the Charter, that court had correctly pointed out that the information contained in the television programme did not relate to the employer's private life, but to her professional conduct, which justified the ongoing interest of the public in having access to that information. In that case, the Bundesverfassungsgericht followed the Melloni line of case law and, on the substance, drew on the findings of the Court of Justice in Google Spain and GC. 152

By contrast, in the other parallel order, the Bundesverfassungsgericht took the view that the matter at issue in the main proceedings was not fully harmonised by the EU legislator, leaving a margin of discretion to the Member States (Gestaltungsspielräume der Mitgliedstaaten). This meant, in essence, that the relevant standard of protection was determined by German fundamental rights. The Bundesverfassungsgericht held, in that regard, that the protection of fundamental rights guaranteed by the Basic Law is presumed to be consistent with the Charter, although that presumption may be rebutted. If that is the case, it is the Charter that becomes the relevant standard of protection.

As to the case at hand, the question was whether a news magazine (Der Spiegel) was obliged to remove from its electronic archives - that were accessible online - the articles it had published concerning a person who had been sentenced to life imprisonment for having committed a double murder in 1981 but who had left prison in 2002. Even though that question fell within the scope of the General Data Protection Regulation, ${ }^{153}$ the Bundesverfassungsgericht observed that it concerned the processing of personal data for journalistic purposes, in respect of which that EU Regulation leaves the Member States a margin of discretion. ${ }^{154}$ Thus, it was for the German courts to engage in a balancing exercise between, on the one hand, the right of personality and, on the other, the freedom of the press, as enshrined in the Basic Law. However, the Bundesgerichtshof had not properly carried out

152 CJEU, Google Spain and Google, judgment of 13 May 2014, case no. C-131/12, EU: C:2014:317, and CJEU, GC and Others (De-referencing of sensitive data), judgment of 24 September 2019, case no. C-136/17, EU:C:2019:773.

153 Regulation (EU) 2016/679 of the European Parliament and of the Council of 27 April 2016 on the protection of natural persons with regard to the processing of personal data and on the free movement of such data, and repealing Directive 95/46/EC (General Data Protection Regulation) OJ 2016 L 119/ 1.

154 BVerfG, Recht auf Vergessen I (n. 150), para. 74. 
such a balancing exercise since it had failed to examine whether it was possible for that magazine to limit the results displayed by the search engines that were associated with the electronic archives when a search was made on the basis of the name of the person concerned, without limiting online access to the articles in question.

In this case, the reasoning of the Bundesverfassungsgericht echoes paragraph 29 of the judgment in Akerberg Fransson, which it expressly cites, ${ }^{155}$ and thus the judgment of the Court of Justice in M.A.S. and M.B.

\section{The Treaties and the Charter as a 'Living Instrument'}

Expressed positively, the autonomy of the EU legal order favours ' $a$ spacious approach to constitutional language'. ${ }^{156}$ This means, in essence, that the Treaties and the Charter are to be construed as 'the basic constitutional charter'157 of the EU and that as such, they provide a 'great outline'. As Chief Justice Marshall famously wrote in McCulloch v. Maryland 200 years ago, 'we must never forget that it is a Constitution we are expounding'. ${ }^{158}$ The philosophy underpinning that famous passage finds an echo in the autonomy of the EU legal order: since the EU legal order is a self-referential system of norms that is both coherent and complete, the Treaties and the Charter must be read with sufficient flexibility in order for the EU legal system 'to endure for ages to come, and consequently to be adapted to the various crises of human affairs'. ${ }^{159}$ The autonomy of the EU legal order enables the Court of Justice to interpret the Treaties and the Charter as a 'living instrument' that takes account of the ongoing changes in the societies of the Member States, ${ }^{160}$ whilst remaining faithful to the immutable values on which the entire EU

155 BVerfG, Recht auf Vergessen I (n. 150), para. 51.

156 Lackland H. Bloom, Methods of Interpretation: How the Supreme Court Reads the Constitution (Oxford: OUP, 2009) 7.

157 CJEU, Les Verts v. Parliament, judgment of 23 April 1986, case no. 294/83, EU: C:1986:166, para. 23.

158 US Supreme Court, McCulloch v. Maryland, 17 U.S. 316, 433 (1819).

159 US Supreme Court, McCulloch v. Maryland, 415.

160 See, in this regard, CJEU, Coman and Others, judgment of 5 June 2018, case no. C-673/ 16, EU:C:2018:385, paras 49 and 50 (where the Court of Justice held that Article 7 of the Charter is to be interpreted as protecting the rights of homosexual couples to have and develop a family life in the same way as heterosexual couples). As to the protection of animals at the time of killing, see Centraal Israëlitisch Consistorie van België and Others, judgment of 17 December 2020, case no. C-336/19, EU:C:2020:1031, para. 77 (holding that 'the Charter is a living instrument which must be interpreted in the light of present-day conditions and of the ideas prevailing in democratic States today'). 
project is founded, such as respect for democracy, fundamental rights, ${ }^{161}$ and the rule of law. ${ }^{162}$ The recent ruling of the Court of Justice in Banco de Santander illustrates this point. ${ }^{163}$

In that case, the question was whether a Spanish Central Tax Tribunal (TEAC) could be considered a 'court or tribunal' within the meaning of Article 267 TFEU. Under Spanish law, the TEAC hears and determines at first and last instance complaints against decisions taken by certain central tax authorities. It is also the appeal body in respect of decisions taken by regional and local tax tribunals (TEAs).

According to the Court of Justice's settled case law, 'in order to determine whether a body making a reference is a 'court or tribunal' for the purposes of Article 267 TFEU, which is a question governed by EU law alone, the Court takes account of a number of factors, such as whether the body is established by law, whether it is permanent, whether its jurisdiction is compulsory, whether the procedure before it is inter partes, whether it applies rules of law and whether it is independent'. In relation to the TEAC, the only issue in dispute was whether that body was independent. In Gabalfrisa, decided in 2000, the Court of Justice replied in the affirmative, finding that Spanish law ensured a separation of functions between, on the one hand, the departments of the tax authority responsible for management, clearance, and recovery and, on the other hand, the TEAs which rule on complaints lodged against the decisions of those departments without receiving any instructions from the tax authority. ${ }^{164}$

However, in Banco de Santander, the Court of Justice held that 'those considerations [had to] be re-examined notably in the light of the most recent case law of the Court concerning, in particular, the criterion of independence'. ${ }^{165}$ Indeed, ever since the ground-breaking judgment of the Court in Associação Sindical dos Juizes Portugueses was decided in 2018, ${ }^{166}$ the Court of Justice has been asked to interpret that criterion in relation to national measures that sought to reduce the salaries of judges, ${ }^{167}$ to lower the retire-

161 CJEU, Schrems I (n. 66).

162 CJEU, Associação Sindical dos Juízes Portugueses, judgment of 27 February 2018, case no. C-64/16, EU:C:2018:117.

163 CJEU, Banco de Santander, judgment of 21 January 2020, case no. C-274/14, EU: C:2020:17.

164 CJEU, Gabalfrisa and Others, judgment of 21 March 2000, joined cases nos C-110/98 to C-147/98, EU:C:2000:145, para. 39.

165 CJEU, Banco de Santander (n. 163), para. 55.

166 CJEU, Associação Sindical dos Juizes Portugueses (n. 162).

167 CJEU, Associação Sindical dos Juízes Portugueses (n. 162). See also CJEU, Escribano Vindel, judgment of 7 February 2019, case no. C-49/18, EU:C:2019:106. 
ment age of sitting judges, ${ }^{168}$ to determine the system governing judicial appointments, ${ }^{169}$ and to establish a new disciplinary regime. ${ }^{170}$

Those cases have given the Court the opportunity to expand further on its findings regarding the two facets of judicial independence. Externally, independence requires that 'the body concerned exercise its functions wholly autonomously'. ${ }^{171}$ In particular, 'the irremovability of the members of the body concerned constitutes a guarantee that is essential to judicial independence in that it serves to protect the person of those who have the task of adjudicating in a dispute'. ${ }^{172}$ This means, in essence, that judges may only be removed either when reaching the obligatory retirement age or upon the expiry of their mandates, unless there are legitimate and compelling grounds for their removal. Internally, the body must be impartial so as to ensure a level playing field between the parties. As to the case at hand, the Court of Justice found that the TEAC did not offer guarantees of independence. The removal of the President and the other members of the TEAC was not limited to legitimate and compelling grounds. Nor was the TEAC impartial given that the Director-General for Taxation of the Ministry of Economy acted as both 'judge and interested party' in cases where an extraordinary appeal for the unification of precedent was brought against a decision of the TEAC. Indeed, that Director General acted both as the appellant and, at the same time, as a member of the eight-person panel called upon to hear the appeal. In addition, the Director-General (or Director) of the competent Department of the State Tax Administration Agency was also part of that panel, despite the fact that the object of that extraordinary appeal was a ruling of the TEAC on the validity of a decision adopted by the body to which that Director-General (or Director) belonged. ${ }^{173}$ This led the Court of Justice to rule that the TEAC was not a 'court or tribunal' within the meaning of Article 267 TFEU.

The judgment of the Court of Justice in Banco de Santander is a clear example of how the Court interprets the Treaties: their meaning is not carved in stone but they are to be read as a living instrument that seeks to strengthen

168 CJEU, Commission v. Poland (Independence of the Supreme Court), judgment of 24 June 2019, case no. C-619/18, EU:C:2019:531, and CJEU, Commission v. Poland (Independence of ordinary courts), judgment of 5 November 2019, case no. C-192/18, EU:C:2019:924.

169 CJEU, A. K. and Others (Independence of the Disciplinary Chamber of the Supreme Court), judgment of 19 November 2019, joined cases nos C-585/18, C-624/18 and C-625/18, EU:C:2019:982, and CJEU, Land Hessen, judgment of 9 July 2020, case no. C-272/19, EU: C:2020:535.

170 CJEU, Commission v. Poland, case no. C-791/19 (currently pending).

171 CJEU, Banco de Santander (n. 163), paras 57-59.

172 CJEU, Banco de Santander (n. 163).

173 CJEU, Banco de Santander (n. 163), para. 74. 
the values on which the EU is founded. By exploring further, the criterion of judicial independence, that judgment not only reinforces the judicial dialogue between the Court of Justice and national courts, which is the 'keystone of the EU judicial system', but also the rule of law within the EU.

\section{Concluding Remarks}

From a normative perspective, the autonomy of the EU legal order is not an end in itself but a means of protecting the core values and structural tenets on which the EU is founded. On the one hand, it operates as a shield against external norms that may constitute a threat to these values and to the EU constitutional framework. On the other hand, autonomy operates as a sword that contributes to defining what European integration is all about, by serving as a guiding compass for the EU to navigate a course through often unchartered waters. Autonomy thus reflects the idea that the Treaties lay down a legal order in its own right, distinct from ordinary international law. In the light of its role to 'ensure that in the interpretation and application of the Treaties the law is observed', the Court of Justice legitimately protects the self-sufficient and coherent system of norms underpinning that legal order, which is the outcome of an ongoing and sometimes arduous process. ${ }^{174}$

However, that concept of autonomy in no way implies that the EU and its law are euro-centric and that the Court of Justice seeks to insulate EU law from external influences by building legal walls that prevent the migration of ideas.

On the contrary, autonomy, as a functional rather than a formal concept, enables the Court of Justice to strike the right balance between the need to preserve the values that we Europeans cherish and wish to preserve for future generations and the openness to other legal orders. Accordingly, the autonomy of the EU legal order is part of the very DNA of the latter allowing the EU to find its own constitutional space whilst interacting in a cooperative way with its Member States and the wider world.

174 See, to that effect, Maciej Szpunar, 'Is the Court of Justice afraid of International Jurisdictions?’, Polish Y. B. Int'l L. (2017), XXXVII, 140. 
